\title{
A first faunistic account on the Onthophagus Latreille, 1802 (Coleoptera, Scarabaeidae, Scarabaeinae) of the Nadia district, West Bengal, with a preliminary checklist from India
}

\author{
Bhim Prasad Kharel ${ }^{1}$, Paul Schoolmeesters ${ }^{2}$, Subhankar Kumar Sarkar ${ }^{1}$ \\ 1 Entomology Laboratory, Department of Zoology, University of Kalyani, Kalyani 741235, West Bengal, India. 2 Langeveldstraat 23, B-3020 \\ Herent, Belgium. \\ Corresponding author: Subhankar Kumar Sarkar, sksarkarzoo18@klyuniv.ac.in
}

\begin{abstract}
A survey of the dung beetle fauna from the Nadia district of West Bengal, India resulted in the recognition of 22 species belonging to Onthophagus Latreille, 1802. All these are new reported for the district. Twelve species are also newly recorded for the West Bengal state: Onthophagus (Onthophagus) andrewesi Arrow, 1931; O. (O.) ceylonicus Harold, 1859; O. (Onthophagiellus) crassicollis Boucomont, 1913; O. (Colobonthophagus) hindu Arrow, 1931; O. (O.) mauritii Boucomont, 1919; O. (Colobonthophagus) paliceps Arrow, 1931; O. (Colobonthophagus) pardalis (Fabricius, 1798); O. (O.) porcus Arrow, 1931; O. (Eremonthophagus) semicinctus d'Orbigny, 1897; O. (O.) socialis Arrow, 1931; $O$. (Indonthophagus) turbatus Walker, 1858; and $O$. (O.) zebra Arrow, 1931. All the recorded taxa are provided with distribution, material examined, diagnostic characters, and remarks. A preliminary checklist of the genus from India based on available literature and physical examination of specimens is also provided.
\end{abstract}

\section{Keywords}

Distribution, dung beetles, faunistic, identification, Onthophagini, Oriental region.

Academic editor: Juan Pablo Botero | Received 30 September 2019 | Accepted 9 March 2020 | Published 3 April 2020

Citation: Kharel BP, Schoolmeesters P, Sarkar SK (2020) A first faunistic account on the Onthophagus Latreille, 1802 (Coleoptera, Scarabaeidae, Scarabaeinae) of the Nadia district, West Bengal, with a preliminary checklist from India. Check List 16 (2): 361-381. https://doi.org/10.15560/16.2.361

\section{Introduction}

The genus Onthophagus Latreille, 1802 is a hyperdiverse and predominant genus within the tribe Onthophagini of the subfamily Scarabaeinae. The subfamily shows a worldwide distribution and currently includes 227 genera and 12 tribes (Chandra and Gupta 2012a), of which the Onthophagini is composed of 35 genera and represents about half of the described species in the entire subfamily (Cambefort 1991; Davis et al. 2002; Smith 2006; Philips 2011). The genus Onthophagus comprises about 3,065 described species-group taxa worldwide: 2,769 living species, 287 infraspecific taxa, and nine extinct species (Schoolmeesters 2019). According to most recent studies, the genus is composed of 30 subgenera (Tarasov and Kabakov 2010; Tarasov and Solodovnikov 2011; Philips 2016).

Beetles belonging to Onthophagus, as well as the other dung beetle genera, are key elements of many ecosystems. By consuming and burying dung, they enhance soil nutrient content, influence soil biota, and increase plant productivity by actively participating in bioturbation (Yokoyama et al. 1991; Mittal 1993; Nichols et al. 2008). Besides, they are also known to augment plant growth, perform secondary seed dispersal, suppress 
abundance of dung-breeding nematodes and protozoan parasites, and play significant ecological role in trophic regulation and pollination (Nichols et al. 2008). Furthermore, the great morphological variety exhibited by Onthophagus beetles (e.g., cephalic and pronotal horns) is very important in evolutionary and developmental biology studies (Moczek 2011; Tarasov and Génier 2015).

The first comprehensive account of Onthophagus beetles from the Oriental region was presented by Arrow (1931). Later monographic works from the Oriental and Palaearctic regions were published by Balthasar (1963) and Löbl and Löbl (2016).

Information on the occurrence of these beetles from India is chiefly based on the following works: Boucomont (1921), Arrow (1931,1933), Oppenheimer (1977), Biswas (1978, 1979), Biswas and Chatterjee (1985, 1986a, 1986b, 1991), Sewak (1985, 1986, 1991, 2004a, 2004b, 2006, 2009a, 2009b, 2010), Scheuren (1995, 1996), Biswas et al. (1999), Chatterjee and Biswas (2000), Saha and Raychaudhuri (2000), Chandra (2000, 2002, 2005, 2009), Chandra and Singh (2004, 2010), Chandra and Ahirwar (2005a, 2005b, 2007), Schoolmeesters and Thomas (2006), Sarkar et al. (2010, 2015), Chandra et al. (2011, 2012a, 2012b, 2012c), Chandra and Gupta (2011a, 2011b, 2012a, 2012b, 2012c, 2012d, 2012e, 2013), Thomas et al. (2011), Jadhav and Sharma (2012), Nithya and Thomas (2012), Anitha Rani and Sanjayan (2013), Karimbumkara and Priyadarsanan (2013, 2016), Bharamal et al. (2014), Gupta et al. (2014), Sathiandran et al.(2015), Gaikwad and Bhawane (2016), Gajendra and Prasad (2016), Singh et al.(2017), Anto and Vinod (2017), and Kalawate (2018).

However, the Scarabaeidae fauna, and specifically Scarabaeinae dung beetles, have never been surveyed in the Nadia district of West Bengal, India. To date, there are no publications on the occurrence of these scarabs from the region. This was the main reason that prompted us to document the scarabaeid fauna of the Nadia district of West Bengal state of India. In this paper, we provide preliminary results on the Onthophagus species that occur in the Nadia district.

Also, we compiled a preliminary checklist of the Onthophagus species known from India using distributional records reported in the literature and direct examination of specimens kept at the Zoological Survey of India (ZSI) (Appendix, Table A1).

\section{Methods}

Study site. Nadia district is located in the West Bengal state of India. The state has $4,064 \mathrm{~km}^{2}$ of forests under protected area network, which correspond to $34 \%$ of the state's total forested area and $4.54 \%$ of its total geographic area. The proportion of agricultural landscape is the highest among the Indian states. West Bengal is divided into 23 districts, and the Nadia district, occupying an area of $3,927 \mathrm{~km}^{2}$ is subdivided into 17 administrative blocks. It is situated at elevations of 7-17 $\mathrm{m}$ above mean sea level and is located between $22^{\circ} 54^{\prime} 02^{\prime \prime}$ and $24^{\circ} 05^{\prime} 55^{\prime \prime} \mathrm{N}$ and between $088^{\circ} 07^{\prime} 52^{\prime \prime}$ and $088^{\circ} 47^{\prime} 35^{\prime \prime} \mathrm{E}$ (Fig. 1). The district lies in the alluvial plains of the river

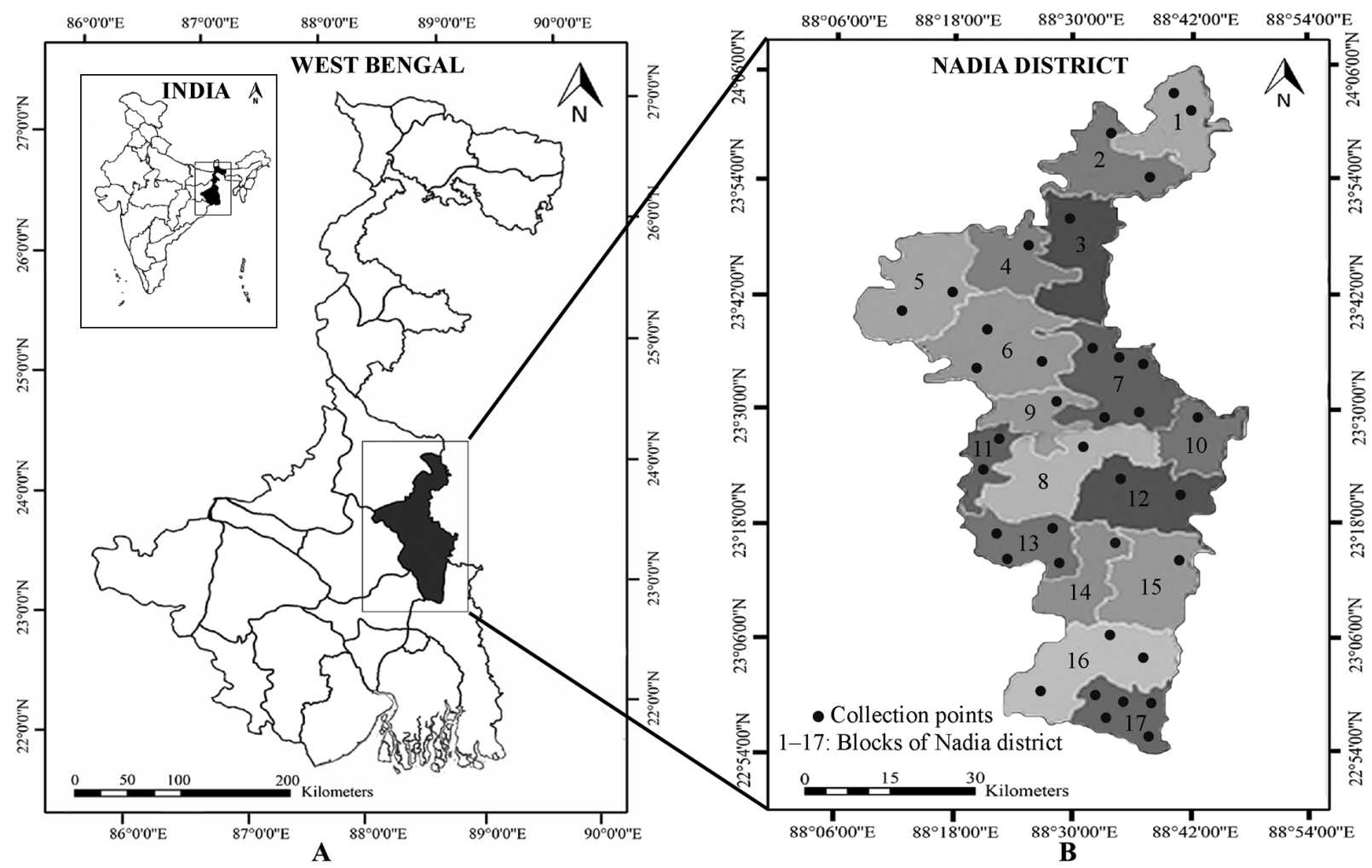

Figure 1. Map of the study area. A. West Bengal state of India (inset) showing Nadia district. B. Nadia district showing collection points and different blocks: $1=$ Karimpur-I, $2=$ Karimpur-II, $3=$ Tehatta-I, $4=$ Tehatta-II, $5=$ Kaliganj, $6=$ Nakashipara, $7=$ Chapra, $8=$ Krishnangar-I, $9=$ Krishnangar-II, $10=$ Krishnangar-III, $11=$ Nabadwip, $12=$ Hanskhali, $13=$ Santipur, $14=$ Ranaghat-I, $15=$ Ranaghat-II, $16=$ Chakdaha, $17=$ Haringhata . 
Ganges and its tributaries and has diverse ecosystems including agricultural lands, grasslands, tropical and evergreen forests, and wetlands.

Data collection, identification, and analysis. Surveys were carried out in various blocks of the district between April 2017 and March 2019. The insects were collected every month and in each block during the period of survey. Beetle specimens were collected by hand and randomly from dung pats, with pitfall traps baited with excrement, including human, cow, buffalo, and pig, among others, and with ultra-violet light traps. The pitfall traps were made of plastic containers $(210 \mathrm{~mm}$ in diameter and $150 \mathrm{~mm}$ in depth) and buried in the soil up to their rims. The traps contained water-formalinliquid soap mixture, a wire grid above the mixture, and about $1 \mathrm{~L}$ of excrement/dung over the wire grid. The traps were placed in four replicates at the study sites during our survey. Dung beetle samples were collected from the traps after every 5-8 days of exposure in the field. After collection, samples were killed by application of chloroform and preserved in $70 \%$ alcohol in glass vials. The collected samples were examined under Sterozoom Binocular Microscope (OLYMPUS SZX7) and identified to species using the literature: Arrow (1931), Balthasar (1963), and Löbl and Löbl (2016). The male genitalia (aedeagus) were dissected and cleaned in $10 \%$ $\mathrm{KOH}$ solution and then transferred in glycerin for further removal of muscles and fats. Species identifications were done using the keys by Arrow (1931). The current taxonomic status of the species was confirmed following Tarasov and Kabakov (2010), Tarasov and Solodovnikov (2011), Philips (2016), and Schoolmeesters (2019). The identified material was also compared with reference specimens housed at the ZSI museum. After species' confirmation, specimens and male genitalia were preserved in $70 \%$ alcohol for future studies. Photographs of adult specimens and genitalia were taken with a camera attached to the microscope.

Material deposition. All insect specimens were deposited in the Kalyani University, Zoology department, Entomology laboratory (KUZEN), West Bengal, India.

\section{Results}

The survey yielded approximately 78 scarab species, and among them 22 are Onthophagus species. All the recorded Onthophagus species are newly recorded for the Nadia district, of which 12 are newly recorded for West Bengal state. Of the 22 new records of Nadia district, Onthophagus (Colobonthophagus) dama (Fabricius, 1798), O. (Colobonthophagus) bison Boucomont, 1919, and O. (Colobonthophagus) triceratops Arrow, 1913 were previously recorded from Jalpaiguri district; $O$. (C.) dama was also recorded from Kolkata district. No other districts of West Bengal have occurrence records for these beetles, and there are no publications available on these species in the Nadia district. Of the recorded species, $O .(C$.) dama is the most dominant species with the greatest number of individuals (65) and the widest distribution throughout the study area, followed by O. (Serrophorus) sagittarius (Fabricius, 1775) with 19 individuals.

In the preliminary checklist of Indian Onthophagus species (Appendix, Table A1), 190 species are known to occur in India. Of these, O. (Colobonthophagus) ramosellus Bates, 1891 is reported from the greatest number of states and union territories (17) and is the most common species of the genus in India.

All the species of Onthophagus recorded by us from the study area are presented below.

Superfamily Scarabaeoidea Latreille, 1802

Family Scarabaeidae Latreille, 1802

Subfamily Scarabaeinae Latreille, 1802

Tribe Onthophagini Burmeister, 1846

Genus Onthophagus Latreille, 1802

Onthophagus (Colobonthophagus) agnus Gillet, 1925 Figure 2A

Material examined (5 ${ }^{\circ}$ ). India, West Bengal, Nadia, Ranaghat (2309'56"N, 088³3'39"E), S.K.Sarkar leg., 11.V.2017, KUZEN S0124-S0125 (2官. India, West Bengal, Nadia, Chakdaha $\left(23^{\circ} 04^{\prime} 50^{\prime \prime} \mathrm{N}, 088^{\circ} 30^{\prime} 57^{\prime \prime} \mathrm{E}\right)$, B.P.Kharel leg., 18.V.2017, KUZEN S0126-S0128 (3ㅇ).

Identification $(q)$. This species can be distinguished from other Onthophagus species by the head semicircular, with a nearly straight and strongly elevated carina on the vertex; clypeus rugulose, with two strong and curved carinae separating it from the forehead; clypeal margin medially reflexed and bilobed; pronotum coarsely punctate, with a blunt tubercle on each side of its anterior elevation; elytra finely striate, with interstriae finely and sparingly punctate; pygidium finely and sparingly punctate.

Geographical distribution. India: Chhattisgarh, Gujarat, Jharkhand, Karnataka, Madhya Pradesh, Maharashtra, Odisha, Rajasthan, Tamil Nadu, and West Bengal (Arrow 1931; Chandra 2000; Chandra and Ahirwar 2007; Sewak 2009a, 2009b, 2010; Chandra and Gupta 2012c, 2012d; Jadhav and Sharma 2012; Chandra and Gupta 2013; Karimbumkara and Priyadarsanan2013; Bharamal et al. 2014; Gupta et al. 2014; Gajendra and Prasad 2016; Kalawate2018).

Remarks. This species is widely distributed throughout India.

\section{Onthophagus (Onthophagus) andrewesi Arrow, 1931} Figure 2B

Material examined ( $\left.1 \sigma^{\Uparrow}\right)$. India, West Bengal, Nadia, Haringhata $\left(22^{\circ} 57^{\prime} 48^{\prime \prime}\right.$ N, 088 $\left.33^{\prime} 41^{\prime \prime} E\right)$, S.K.Sarkar leg., 03.VIII.2017, KUZEN S0129 (1ð゙).

Identification $(\precsim)$. This species can be distinguished from other Onthophagus species by the head broad, with rounded sides and a pair of backwardly produced 


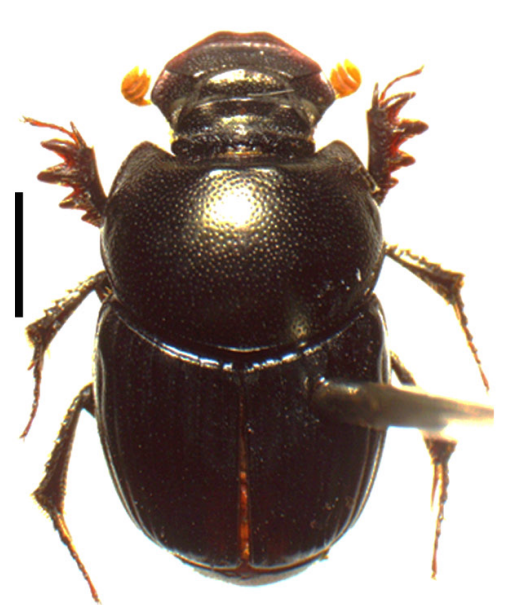

A

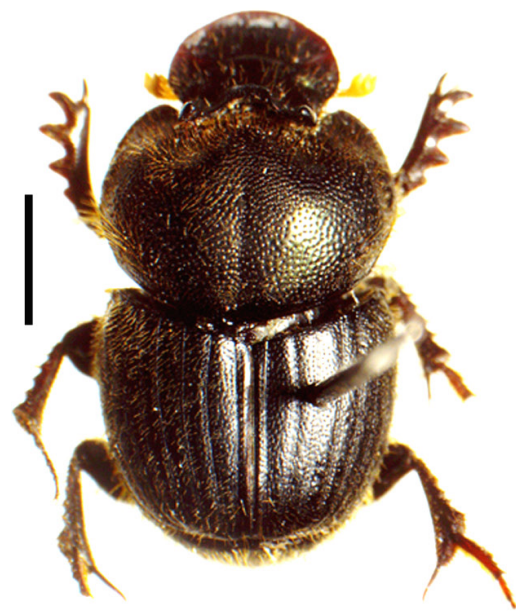

B

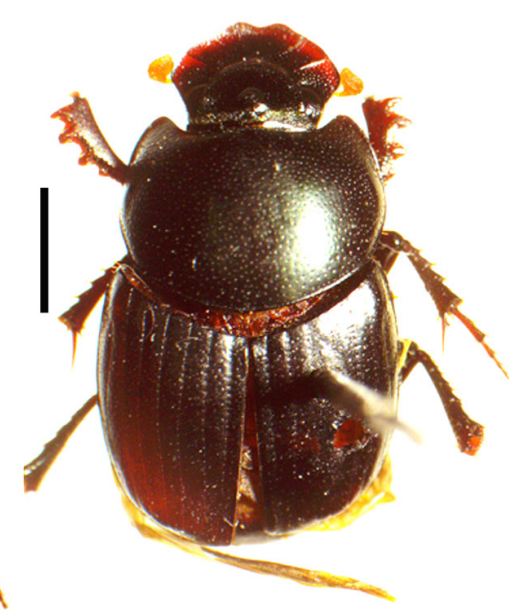

C

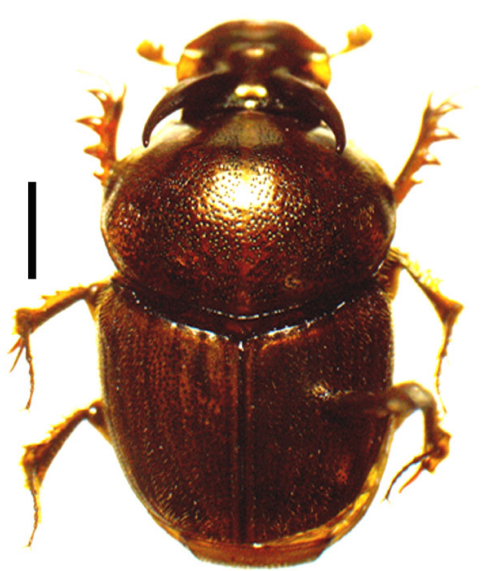

D

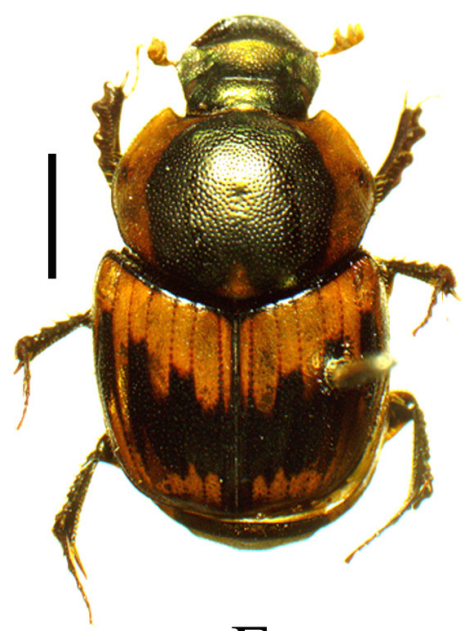

E

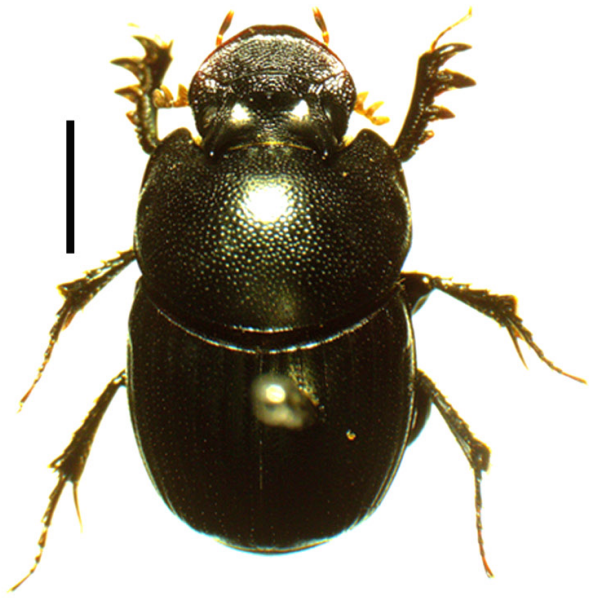

F
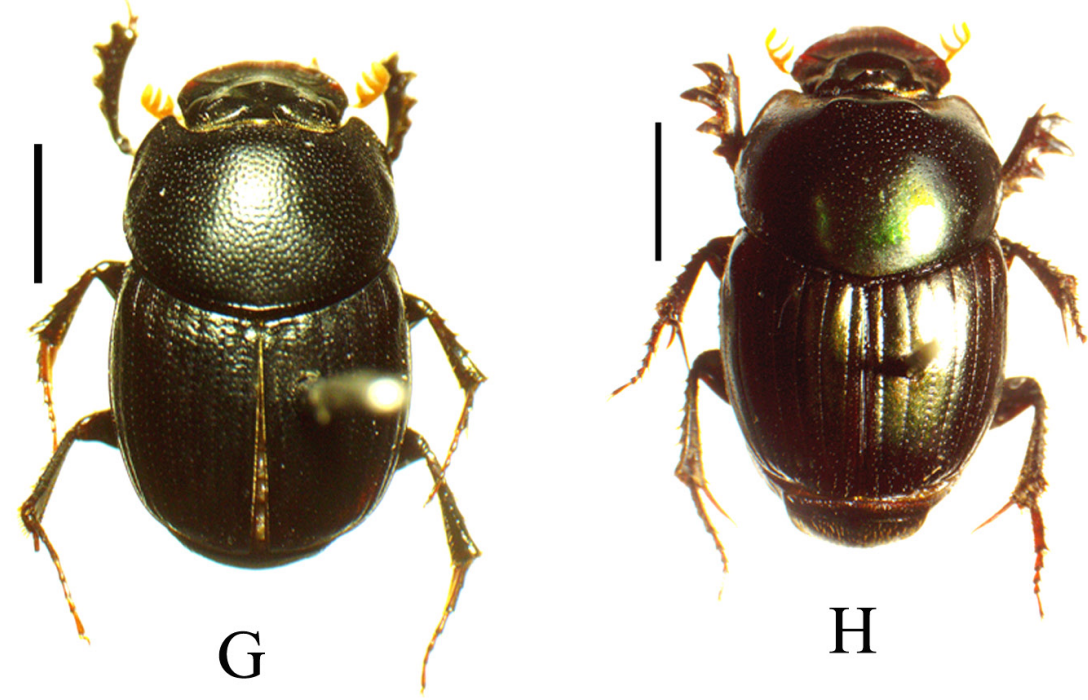

Figure 2. Dorsal habitus of adults of Onthophagus Latreille, 1802 species recorded from Nadia district of West Bengal, India. A. Onthophagus (Colobonthophagus) agnus Gillet, 1925 \%. B. Onthophagus (Onthophagus) andrewesi Arrow, 1931 . C. Onthophagus (Colobonthophagus) bison Boucomont, 1919 J. D. Onthophagus (Onthophagus) cervus (Fabricius, 1798) J. E. Onthophagus (Onthophagus) ceylonicus Harold, 1859 ․ F. Onthophagus (Onthophagus) circulifer Arrow, 1931 . G. Onthophagus (Onthophagus) circulifer Arrow, 1931 +. H. Onthophagus (Onthophagiellus) crassicollis Boucomont, 1913 . . Scale bars $=2 \mathrm{~mm}$. 
recurved horns on the vertex; clypeus produced, with a slightly rounded carina separating it from the forehead; pronotum coarsely punctate, with a mid-longitudinal groove and blunt front angles; elytra finely striate, with interstriae minutely granulate; pygidium sparingly punctate.

Geographical distribution. India: Karnataka, Kerala, Maharashtra, and Tamil Nadu (Arrow 1931; Biswas and Chatterjee 1986b; Chandra 2009; Karimbumkara and Priyadarsanan 2013; Sathiandran et al. 2015).

Remarks. This species is newly recorded for West Bengal state.

\section{Onthophagus (Colobonthophagus) bison Boucomont, 1919}

Figure 2C

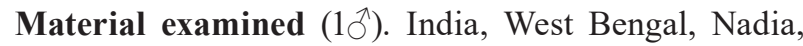
Karimpur $\left(23^{\circ} 58^{\prime} 31^{\prime \prime}\right.$ N, 088 $\left.37^{\prime} 32^{\prime \prime} E\right)$, S.K.Sarkar leg., 08.V.2017, KUZEN S0130 (1ठึ).

Identification $(\widehat{\circlearrowleft})$. This species can be distinguished from other Onthophagus species by the short and broad head; clypeus rugose, with a posterior sharp curved carina, and margin semicircular; pronotum strongly and closely punctate, with blunt front angles; elytra strongly striate, with flat and sparsely punctate interstriae; metaventrite nearly smooth, shielded with few minute punctures laterally.

Geographical distribution. Myanmar, and Thailand (Arrow 1931; Schoolmeesters 2019). India: Arunachal Pradesh, and West Bengal (Arrow 1931; Sewak 2006; Sarkar et al. 2015; Schoolmeesters 2019).

\section{Onthophagus (Onthophagus) cervus (Fabricius, 1798)} Figure 2D

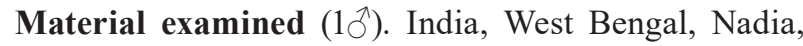
Hanskhali $\left(23^{\circ} 21^{\prime} 40^{\prime \prime} \mathrm{N}, 088^{\circ} 35^{\prime} 56^{\prime \prime} \mathrm{E}\right)$, B.P.Kharel leg., 05.VII.2018, KUZEN S0131 (1ठ̋).

Identification $(\widehat{O})$. This species can be distinguished from other Onthophagus species by the head narrow, with rounded sides and a pair of long, backwardly sloping, and internally curved horns on the vertex; clypeus truncate, little produced but not pointed, and separated from the forehead by a feeble carina; pronotum strongly, unevenly, and scantily punctate, with sharp front angles; elytra finely striate, with slightly convex and finely punctate interstriae; pygidium coarsely and finely punctate.

Geographical distribution. Pakistan, Saudi Arabia, Sri Lanka, and Vietnam (Sewak 2009a; Biswas and Chatterjee 1986a). India: Andaman and Nicobar Islands, Arunachal Pradesh, Chhattisgarh, Gujarat, Karnataka, Kerala, Madhya Pradesh, Maharashtra, Puducherry, Rajasthan, Tamil Nadu, Uttarakhand, Uttar Pradesh, and West Bengal (Arrow 1931; Biswas and Chatterjee 1986a; Chandra 2000; Chandra and Ahirwar 2005a, 2005b, 2007; Sewak 2006, 2009a, 2009b, 2010; Jadhav and Sharma 2012; Chandra et al. 2012b; Chandra and Gupta 2012c, 2012d, 2013; Anitha Rani and Sanjayan 2013, Karimbumkara and Priyadarsanan 2013; Sathiandran et al. 2015; Gajendra and Prasad 2016).

Remarks. This species is widely distributed throughout India.

Onthophagus (Onthophagus) ceylonicus Harold, 1859 Figure 2E

Material examined (2 + ). India, West Bengal, Nadia, Haringhata $\left(22^{\circ} 57^{\prime} 54^{\prime \prime} \mathrm{N}, 088^{\circ} 33^{\prime} 37^{\prime \prime} \mathrm{E}\right)$, B.P.Kharel leg., 15.IX.2018, KUZEN S0132-S0133 (29).

Identification ( + ). This species can be distinguished from other Onthophagus species by the testaceous yellow body colour, with the head, central part of pronotum, longitudinal stripes upon the elytra, and propygidium black; head broad, laterally rounded, with a strong, straight, and transverse ridge on the vertex; clypeus nearly rounded and little reflexed in front, separated from the forehead by a strong and medially raised carina; pronotum strongly punctate, with blunt front angles; elytra strongly striate, with convex and scantily punctate interstriae; pygidium finely and scantily punctate.

Geographical distribution. Sri Lanka (Arrow 1931; Harold 1859). India: Karnataka, and Rajasthan (Arrow 1931; Sewak 2006, 2009a).

Remarks. This species is newly recorded for West Bengal state.

\section{Onthophagus (Onthophagus) circulifer Arrow, 1931 Figure 2F, G}

Material examined $(1 \hat{\jmath}, 1$ 우). India, West Bengal, Nadia, Nabadwip $\left(23^{\circ} 23^{\prime} 57^{\prime \prime} N\right.$, $088^{\circ} 22^{\prime} 08^{\prime \prime}$ E), S.K.Sarkar leg., 08.VII.2018, KUZEN S0134 (1ठ̋), KUZEN S0135 (19).

Identification $(\widehat{\jmath})$. This species can be distinguished from other Onthophagus species by the uniform dorsal colour; head broad, with sparse punctures and a pair of backwardly inclined, and short parallel horns on the vertex, basally fused by a medially toothed carina; clypeus produced and bilobed anteriorly; pronotum strongly convex and annularly punctate; elytra shallowly striate, with interstriae flat and minutely granulate; pygidium coarsely and annularly punctate.

Geographical distribution. Myanmar (Arrow 1931; Karimbumkara and Priyadarsanan 2013). India: Assam, Haryana, Jammu and Kashmir, Maharashtra, Meghalaya, Punjab, Sikkim, Uttarakhand, Uttar Pradesh, and West Bengal (Arrow 1931; Chandra et al. 2012a, 2012c; Karimbumkara and Priyadarsanan 2013, 2016).

Remarks. This species is widely distributed throughout the country.

\section{Onthophagus (Onthophagiellus) crassicollis Boucomont, 1913 \\ Figure $2 \mathrm{H}$}

Material examined (2 + ). India, West Bengal, Nadia, 
Kaliganj $\left(23^{\circ} 44^{\prime} 02^{\prime \prime} \mathrm{N}, 088^{\circ} 14^{\prime} 02^{\prime \prime} \mathrm{E}\right)$, B.P.Kharel leg., 01.VI.2018, KUZEN S0136-S0137 (29).

Identification $(+)$. This species can be distinguished from other Onthophagus species by the head narrow, with a straight and strongly elevated carina on the vertex , and a second curved carina on the forehead; clypeus ogival, rounded, and little reflexed anteriorly, transversely rugose, and separated from forehead by a feeble carina; pronotum strongly and closely punctate, with two anterior prominences; elytra finely striate, with flat interstriae; metatarsomere I long, about four times the length of metatarsomere II; pygidium sparsely punctate.

Geographical distribution. China, Iran, Malaysia, Myanmar, Thailand, and Vietnam (Arrow 1931; Schoolmeeters 2019). India: Arunachal Pradesh, and Rajasthan (Arrow 1931; Biswas and Chatterjee 1985; Sewak 2006, 2009a, 2009b; Muhaimin et al. 2015; Schoolmeeters 2019).

Remarks. This species is newly recorded for West Bengal state.

\section{Onthophagus (Colobonthophagus) dama (Fabricius, 1798)}

Figure 3A, B

Material examined $(26 \hat{\jmath}, 39+)$. India, West Bengal, Nadia, Karimpur $\left(23^{\circ} 58^{\prime} 12^{\prime \prime} \mathrm{N}, 088^{\circ} 37^{\prime} 12^{\prime \prime} \mathrm{E}\right)$, S.K.Sarkar leg., 08.V.2017, KUZEN S0138-S0141 (4○ึ). India, West Bengal, Nadia, Kaliganj $\left(23^{\circ} 44^{\prime} 03^{\prime \prime} \mathrm{N}, 088^{\circ} 13^{\prime} 57^{\prime \prime} \mathrm{E}\right)$

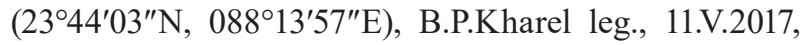
KUZEN S0142-S0143 (2q). India, West Bengal, Nadia, Krishnanagar $\left(23^{\circ} 23^{\prime} 59^{\prime \prime} \mathrm{N}, 088^{\circ} 30^{\prime} 37^{\prime \prime} \mathrm{E}\right)$, B.P.Kharel leg., 01.VI.2018, KUZEN S0144-S0146 (3ㅇ), KUZEN S0147-S0151 (5 $\left.{ }^{\top}\right)$. India, West Bengal, Nadia, Nabadwip $\left(23^{\circ} 24^{\prime} 11^{\prime \prime} \mathrm{N}, 088^{\circ} 22^{\prime} 5^{\prime \prime} \mathrm{E}\right)$, S.K.Sarkar leg., 03.VI.2018, KUZEN S0152-S0154 (3), KUZEN S0155-S0157 $\left(3 \bigcirc^{\Uparrow}\right)$. India, West Bengal, Nadia, Santipur $\left(23^{\circ} 15^{\prime} 56^{\prime \prime} \mathrm{N}\right.$, $088^{\circ} 26^{\prime} 10^{\prime \prime}$ ), S.K.Sarkar leg., 08.VII.2018, KUZEN S0158-S0163 (6ㅇ), KUZEN S0164-S0171 (8今̄). India, West Bengal, Nadia, Haringhata $\left(22^{\circ} 57^{\prime} 49^{\prime \prime} \mathrm{N}\right.$, 088 33'36"E), S.K.Sarkar leg., 10.VII.2018, KUZEN S0172-S0179 (8). India, West Bengal, Nadia, Hanskhali $\left(23^{\circ} 21^{\prime} 56^{\prime \prime} \mathrm{N}, \quad 088^{\circ} 36^{\prime} 07^{\prime \prime} \mathrm{E}\right), \quad$ B.P.Kharel leg., 05.VIII.2018, KUZEN S0180-S0185 (6). India, West

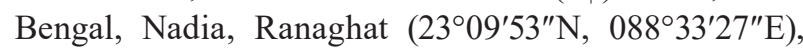
B.P.Kharel leg., 09.III.2019, KUZEN S0186-S0192 (7ㅇ). India, West Bengal, Nadia,Tehatta $\left(23^{\circ} 43^{\prime} 53^{\prime \prime} \mathrm{N}\right.$, 088 31'44"E), S.K.Sarkar leg., 22.VIII.2018, KUZEN S0193-S0198 (6 $\left.{ }^{\top}\right)$. India, West Bengal, Nadia, Chapra $\left(23^{\circ} 30^{\prime} 50^{\prime \prime} \mathrm{N}, 088^{\circ} 32^{\prime} 56^{\prime \prime} \mathrm{E}\right)$, B.P.Kharel leg., 23.IX.2018, KUZEN S0199-S0202 (4).

Identification $\left({ }^{\Uparrow}\right)$. This species can be distinguished from other Onthophagus species by the body entirely glabrous dorsally; head short and broad, with a pair of long, backwardly inclined, outwardly curved, and toothed horns on the vertex; clypeus strongly punctate; clypeal margin semi-circular and medially slightly projected; pronotum finely and sparsely punctate, with the sides nearly rounded and basal margins slightly angulate medially; elytra distinctly striate, with interstria enearly flat and finely and scarcely punctate; pygidium moderately punctate.

Geographical distribution. Bhutan, China, Nepal, and Sri Lanka (Arrow1931; Biswas and Chatterjee 1986a; Singh et al. 2017). India: Arunachal Pradesh, Bihar, Chhattisgarh, Haryana, Himachal Pradesh, Karnataka, Kerala, Madhya Pradesh, Maharashtra, Odisha, Sikkim, Tamil Nadu, Uttarakhand, Uttar Pradesh, and West Bengal (Arrow 1931; Biswas and Chatterjee 1985, 1986a, 1991; Chandra 2000, 2005; Chandra and Ahirwar 2005a, 2005b, 2007; Sewak 2006; Chandra and Gupta 2011a, 2012c, 2012d, 2012e, 2013; Jadhav and Sharma 2012; Chandra et al. 2012a, 2012b, 2012c; AnithaRani and Sanjayan2013; Karimbumkara and Priyadarsanan 2013; Bharmal et al. 2014; Gupta et al. 2014; Sarkar et al. 2015; Sathiandran et al. 2015; Gajendra and Prasad 2016; Singh et al. 2017; Kalawate 2018).

Remarks. This species is widely distributed throughout the country.

\section{Onthophagus (Colobonthophagus) hindu Arrow, 1931 Figure 3C}

Material examined (2 + ). India, West Bengal, Nadia, Santipur ( $23^{\circ} 15^{\prime} 57^{\prime \prime N}$, 088 $\left.26^{\prime} 20^{\prime \prime} E\right)$, B.P.Kharel leg., 23.VIII.2018, KUZEN S0203-S0204 (29).

Identification ( + ). This species can be distinguished from other Onthophagus species by the head broad and round, with a short tubercle in the middle of the posterior margin; clypeus bluntly bilobed, with a transverse carina separating it from the forehead; pronotum finely and closely punctate, with the sides and basal margin gently rounded; elytra with flat and sparsely punctate interstriae; pygidium finely and sparsely punctate.

Geographical distribution. Afghanistan, Pakistan, and Sri Lanka (Chandra et al. 2012b; Gupta et al. 2014). India: Andhra Pradesh, Chhattisgarh, Jammu and Kashmir, Karnataka, Madhya Pradesh, and Maharashtra (Arrow 1931; Chandra and Gupta 2011a, 2011b, 2012c, 2012d, 2013; Chandra et al. 2012b; Karimbumkara and Priyadarsanan 2013, 2016; Gupta et al. 2014; Siddiqui et al. 2014; Gajendra and Prasad 2016; Kalawate2018).

Remarks. This species is newly recorded for West Bengal state.

\section{Onthophagus (Onthophagus) mauritii Boucomont, 1919}

Figure 3D

Material examined (1ㅇ). India, West Bengal, Nadia, Chapra (2330'41"N, 088 33'01"E), S.K.Sarkar leg., 12. IX.2018, KUZEN S0205 (1ㅇ).

Identification ( + ). This species can be distinguished from other Onthophagus species by the head short and broad; clypeus rugosely punctate, separated from the forehead by a curved carina, with anterior margin feebly 


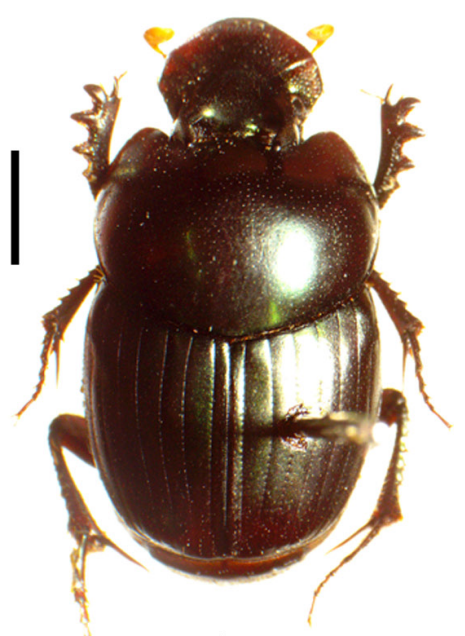

A

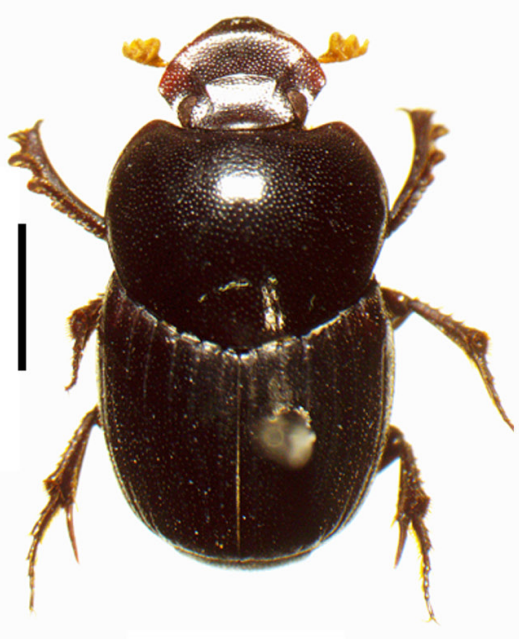

$\mathrm{D}$

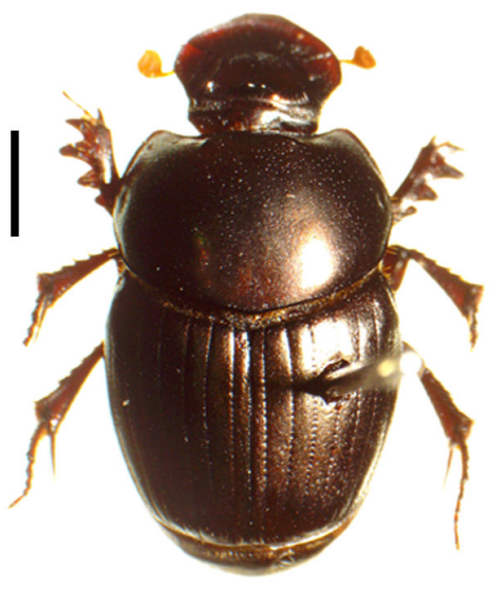

$\mathrm{B}$
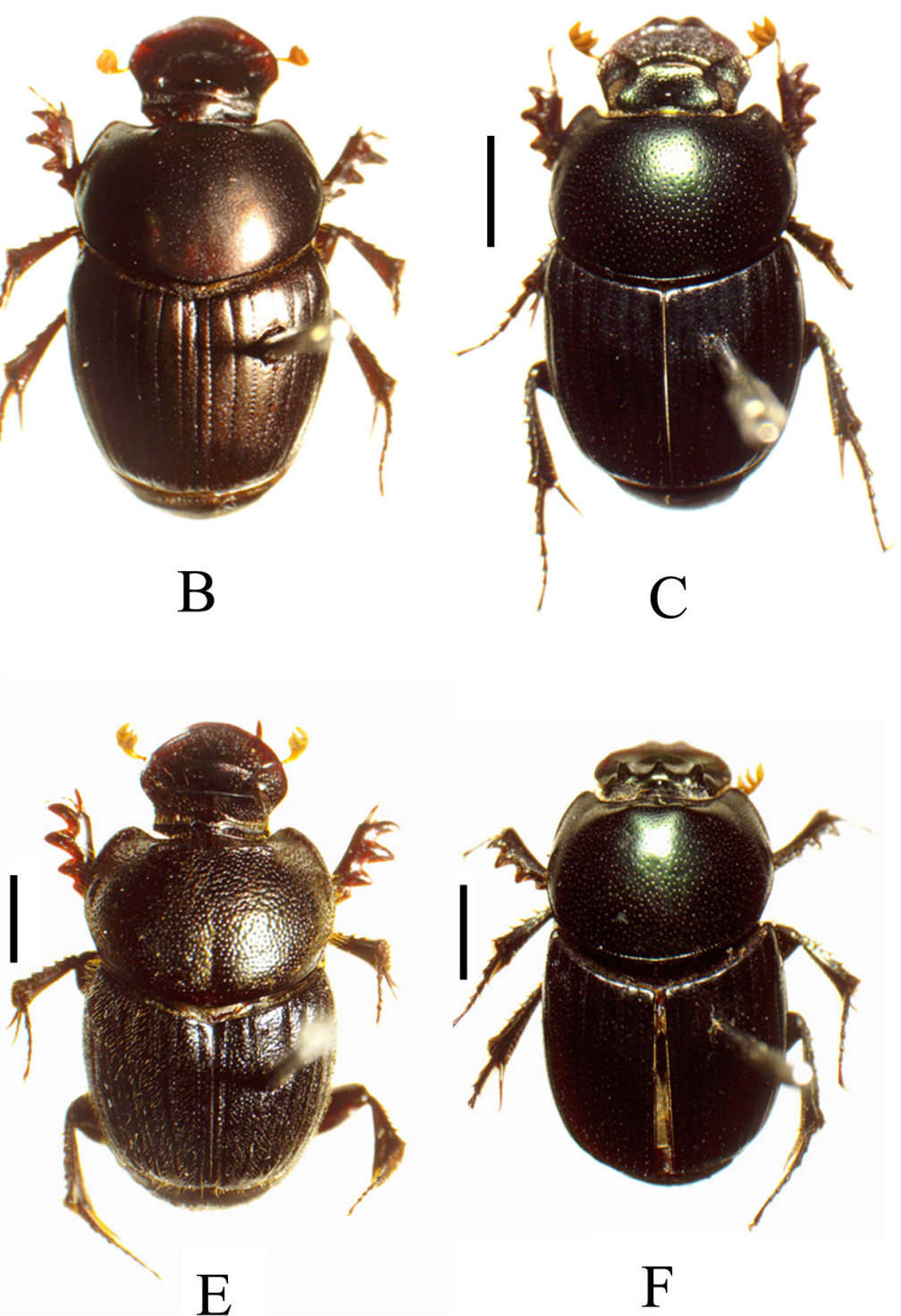

$\mathrm{F}$
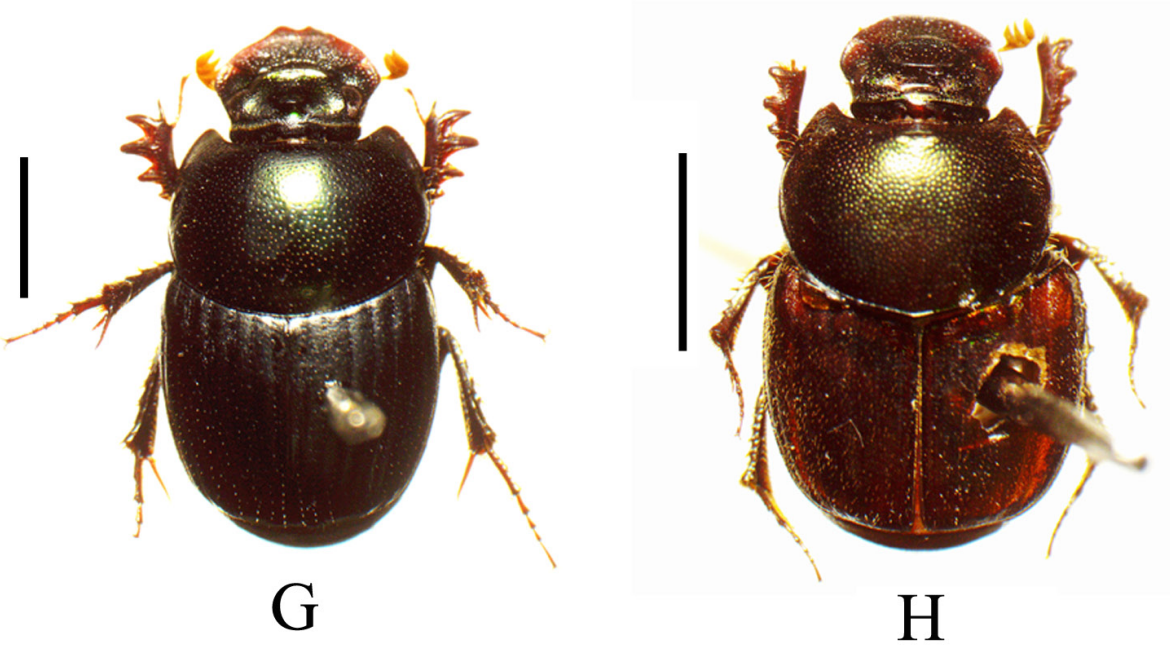

Figure 3. Dorsal habitus of male/female of Onthophagus Latreille, 1802 species recorded from Nadia district of West Bengal, India. A. Onthophagus (Colobonthophagus) dama (Fabricius, 1798) ô. B. Onthophagus (Colobonthophagus) dama (Fabricius, 1798) q. C. Onthophagus (Colobonthophagus) hindu Arrow, 1931 +. D. Onthophagus (Onthophagus) mauritii Boucomont, 1919 \%. E. Onthophagus (Indonthophagus) mopsus (Fabricius, 1792) +. F. Onthophagus (Colobonthophagus) paliceps Arrow, 1931 . G. Onthophagus (Colobonthophagus) pardalis Boucomont, 1914 + . H. Onthophagus (Onthophagus) porcus Arrow, 1931 ^. Scale bars $=2 \mathrm{~mm}$. 
sinuate; pronotum convex and uniformly punctate; elytra finely striate; pygidium coarsely punctate.

Geographical distribution. India: Arunachal Pradesh, Bihar, Karnataka, Maharashtra, and Tamil Nadu (Arrow 1931; Biswas and Chatterjee 1985; Sewak 2006; Chandra 2009; Karimbumkara and Priyadarsanan 2013).

Remarks. This species is newly recorded for West Bengal state.

\section{Onthophagus (Indonthophagus) mopsus (Fabricius, 1792)}

Figure 3E

Material examined (19). India, West Bengal, Nadia, Krisnanagar $\left(23^{\circ} 24^{\prime} 20^{\prime \prime} \mathrm{N}, \quad 088^{\circ} 30^{\prime} 17^{\prime \prime} \mathrm{E}\right)$, B.P.Kharel leg., 12.V.2017, KUZEN S0206 (19).

Identification ( $($ ). This species can be distinguished from other Onthophagus species by the head broad; clypeus rugosely punctate, with anterior margin rounded, reflexed, and separated from the forehead by a curved carina; pronotum finely and densely punctate, with a lateral scarce impression posteriorly; elytra finely striate; pygidium strongly punctate; metaventrite densely punctate laterally.

Geographical distribution. Afghanistan and Pakistan (Arrow 1931; Singh et al. 2017). India: Bihar, Chandigarh, Himachal Pradesh, Jammu and Kashmir, Karnataka, Madhya Pradesh, Punjab, Rajasthan, Sikkim, Uttarakhand, Uttar Pradesh, and West Bengal (Arrow 1931; Chandra 2005; Chandra and Gupta 2012c, 2012d); Karimbumkara and Priyadarsanan 2013; Singh et al. 2017).

Remarks. This species is widely distributed throughout the country.

\section{Onthophagus (Colobonthophagus) paliceps Arrow, 1931}

Figure 3F

Material examined (1 $\overbrace{}^{\Uparrow})$. India, West Bengal, Karimpur (2358'27"N, 088 37'25"E), B.P.Kharel leg., 08.V.2017, KUZEN S0207 (1ठ゚).

Identification ( $\left.\delta^{\pi}\right)$. This species can be distinguished from other Onthophagus species by the head bearing a short, slender and upwardly curved median horn, along with a pair of short, transverse and rectangular erect process arising from the inner margin of each eye; forehead minutely punctate; pronotum minutely and sparsely punctate, with the anterior angles bluntly produced and posterior margin slightly rounded; front tibia with short and spatulate terminal spur.

Geographical distribution. Pakistan (Siddiqui et al. 2014). India: Karnataka, Madhya Pradesh, and Uttarakhand (Arrow 1931; Chandra and Gupta 2012c, 2012d; Karimbumkara and Priyadarsanan 2013; Siddiqui et al. 2014).

Remarks. This species is newly recorded for West Bengal state.

\section{Onthophagus (Colobonthophagus) pardalis}

(Fabricius, 1798)

Figure $3 \mathrm{G}$

Material examined (2 + ). India, West Bengal, Nadia, Haringhata $\left(22^{\circ} 57^{\prime} 42^{\prime \prime} \mathrm{N}, 088^{\circ} 33^{\prime} 46^{\prime \prime} \mathrm{E}\right)$, B.P.Kharel leg., 10.I.2019, KUZEN S0208-S0209 (2ㅇ).

Identification ( 9 ). This species can be distinguished from other Onthophagus species by the head broad and anteriorly semicircular, vertex with a short and basally broad horn; clypeus transversely rugose, with a feebly curved fronto-clypeal carina separating it from the forehead and another straight carina just behind; clypeal margin strongly reflexed and bilobed; elytra finely striate, with interstriae slightly convex and closely punctate; protibia with slender and curved spur.

Geographical distribution. India: Karnataka, Maharashtra, and Tamil Nadu (Arrow 1931; Chandra 2009; Karimbumkara and Priyadarsanan2013).

Remarks. This species is newly recorded for West Bengal state.

\section{Onthophagus (Onthophagus) porcus Arrow, 1931} Figure $3 \mathrm{H}$

Material examined $\left(1 \delta^{\Uparrow}\right)$. India, West Bengal, Nadia, Nakashipara $\left(23^{\circ} 35^{\prime} 19^{\prime \prime} \mathrm{N}, \quad 088^{\circ} 21^{\prime} 08^{\prime \prime} \mathrm{E}\right)$, S.K.Sarkar leg., 11.IX.2018, KUZEN S0209 (1ठ̋).

Identification $(\precsim)$. This species can be distinguished from other Onthophagus species by the head narrow and curved laterally, strongly punctate, with a straight and strongly elevated carina upon the vertex; clypeus rounded, with a curved carina separating it from the forehead; pronotum finely and closely punctate, with anterior angles fairly sharp; elytra finely striate, with intervals flat and closely punctate; pygidium closely punctate.

Geographical distribution. Bangladesh (Biswas and Chatterjee 1985). India: Arunachal Pradesh, and Karnataka (Arrow 1931; Biswas and Chatterjee 1985; Sewak 2006; Karimbumkara and Priyadarsanan 2013).

Remarks. This species is newly recorded for West Bengal state.

\section{Onthophagus (Colobonthophagus) quadridentatus (Fabricius, 1798)}

Figure 4A

Material examined (3ㅇ). India, West Bengal, Nadia, Krishnanagar $\left(23^{\circ} 24^{\prime} 14^{\prime \prime} \mathrm{N}, 088^{\circ} 30^{\prime} 05^{\prime \prime} \mathrm{E}\right)$, B.P.Kharel leg., 30.IX.2018, KUZEN S0210-S0212 (3ㅇ).

Identification ( + ). This species can be distinguished from other Onthophagus species by the head broad, with a transverse carina on the vertex and another strongly elevated carina on the forehead; clypeus rugose, with a strong and nearly straight carina separating it from the forehead; clypeal margin rounded and strongly reflexed; pronotum strongly punctate, with lateral margins slightly sinuate anteriorly, and posteriorly rounded; 


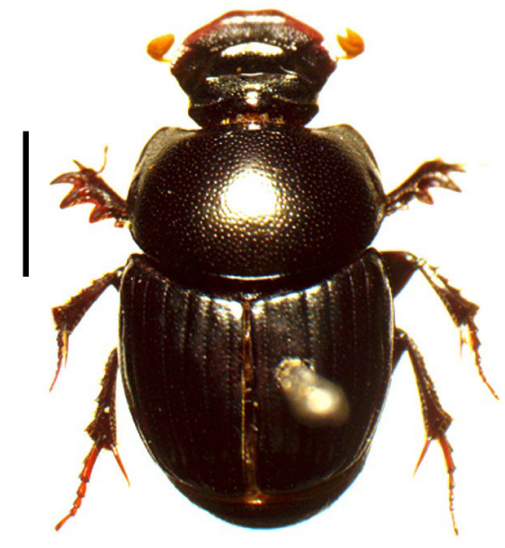

A
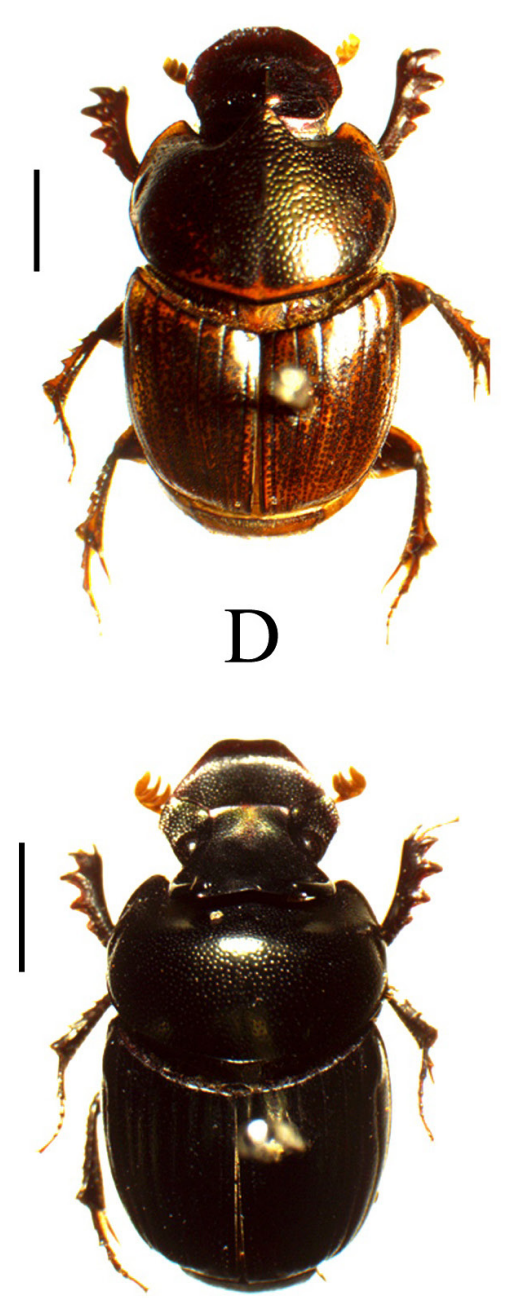

G

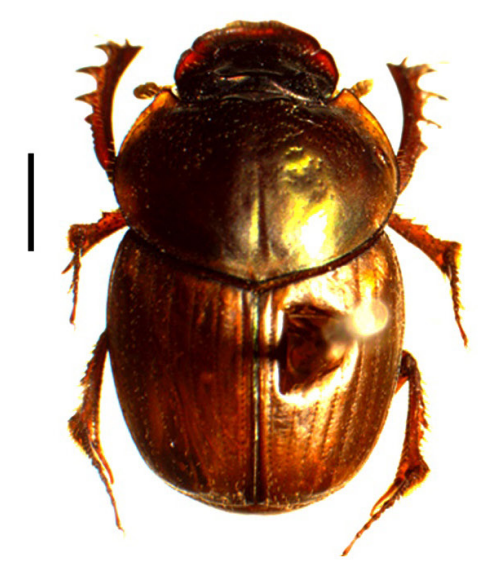

$\mathrm{B}$

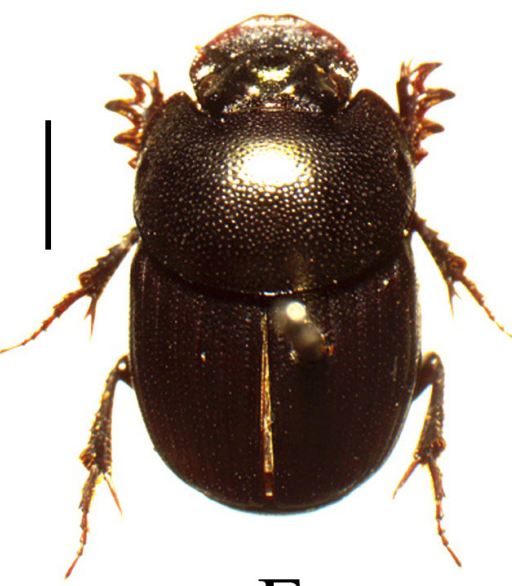

$\mathrm{E}$

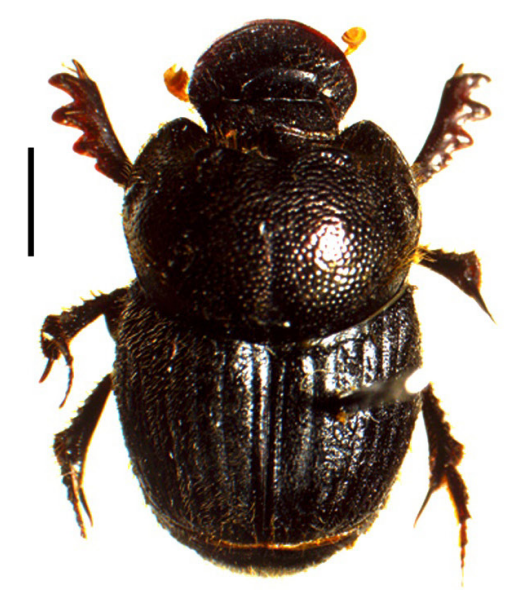

$\mathrm{H}$
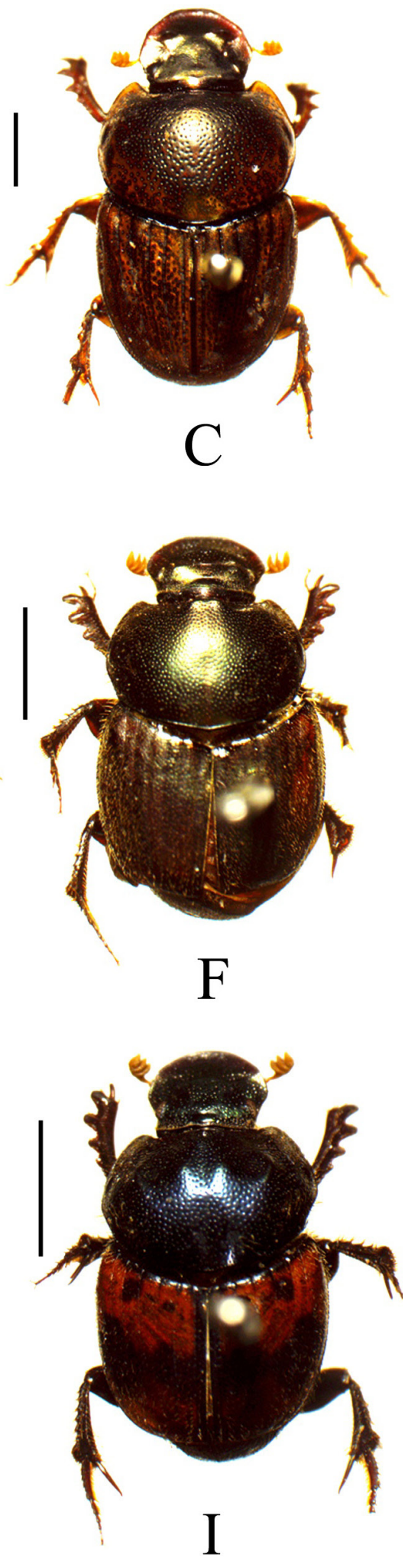

Figure 4. Dorsal habitus of male/female of Onthophagus Latreille, 1802 species recorded from Nadia district of West Bengal, India. A. Onthophagus (Colobonthophagus) quadridentatus (Fabricius, 1798) $q$. B. Onthophagus (Serrophorus) rectecornutus Lansberge, $1883 \AA$. C. Onthophagus (Serrophorus) Sagittarius (Fabricius, 1775) ${ }^{1}$. D. Onthophagus (Serrophorus) Sagittarius (Fabricius, 1775) q. E. Onthophagus (Eremonthophagus) semicinctus d'Orbigny, 1897 +. F. Onthophagus (Onthophagus) socialis Arrow, 1931 9 . G. Onthophagus (Colobonthophagus) triceratops Arrow, 1913 . H. Onthophagus (Indonthophagus) turbatus Walker, 1858 q. I. Onthophagus (Onthophagus) zebra Arrow, 1931 . Scale bars $=2 \mathrm{~mm}$. 
elytra shining and strongly striate, with flat interstriae; pygidium opaque and finely punctate.

Geographical distribution. Pakistan, Sri Lanka, and Taiwan (Arrow 1931; Biswas and Chatterjee 1986a; Gupta et al. 2014). India: Arunachal Pradesh, Assam, Bihar, Chhattisgarh, Himachal Pradesh, Karnataka, Kerala, Madhya Pradesh, Maharashtra, Odisha, Punjab, Rajasthan, Tamil Nadu, Uttarakhand, Uttar Pradesh, and West Bengal (Arrow 1931; Biswas and Chatterjee 1986a, 1991; Chandra 2000, 2005; Chandra and Ahirwar 2005a, 2007; Chandra and Gupta 2011a, 2012c, 2012d, 2012e, 2013; Chandra et al. 2012b, 2012c; Karimbumkara and Priyadarsanan 2013; Gupta et al. 2014; Siddiqui et al. 2014; Gajendra and Prasad 2016; Anto and Vinod 2017).

Remarks. This species is widely distributed throughout the country.

\section{Onthophagus (Serrophorus) rectecornutus Van Lansberge, 1883 \\ Figure 4B}

Material examined (1 $\left.\delta^{\Uparrow}\right)$. India, West Bengal, Nadia,

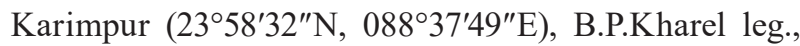
10.XII.2018, KUZEN S0213 (1ठ)).

Identification $(\hat{\sigma})$. It can be distinguished from other Onthophagus species by the head short and broad, with a pair of straight, backwardly directed, and divergent horns on the vertex; clypeus semicircular, with a short and acuminate anterior carina; clypeal margin entire and strongly reflexed; pronotum anteriorly granular, with a longitudinal sulcus present medially, laterally slightly curved, posteriorly strongly rounded, and anterior angles sharp; elytra deeply striate, with interstriae finely punctate.

Geographical distribution. Bangladesh, Bhutan, Malaysia, Myanmar, Sri Lanka, Thailand, and Vietnam (Arrow 1931; Schoolmeesters 2019). India: Arunachal Pradesh, Assam, Bihar, Karnataka, Kerala, Nagaland, Tamil Nadu, Tripura, Uttarakhand, and West Bengal (Arrow 1931; Biswas and Chatterjee 1985, 1986a; Chatterjee and Biswas 2000; Sewak 2006; AnithaRani and Sanjayan2013; Karimbumkara and Priyadarsanan 2013; Muhaimin et al. 2015; Sathiandran et al. 2015; Schoolmeesters 2019).

Remarks. This species is widely distributed throughout the country.

\section{Onthophagus (Serrophorus) Sagittarius (Fabricius, 1775)}

Figure 4C, D

Material examined (12 $\hat{\jmath}, 7$ 우). India, West Bengal, Nadia, Haringhata $\left(22^{\circ} 57^{\prime} 48^{\prime \prime} \mathrm{N}, 088^{\circ} 33^{\prime} 45^{\prime \prime} \mathrm{E}\right)$, S.K.Sarkar leg, 10.IX.2018, KUZEN S0214-S0215 (2ㅇ). India, West Bengal, Nadia, Nakashipara $\left(23^{\circ} 35^{\prime} 07^{\prime \prime} \mathrm{N}, 088^{\circ} 20^{\prime} 57^{\prime \prime} \mathrm{E}\right)$, B.P.Kharel leg., 20.IX.2018, KUZEN S0216-S0219 $\left(4 \bigcirc^{\Uparrow}\right)$. India, West Bengal, Nadia, Santipur $\left(23^{\circ} 16^{\prime} 01^{\prime \prime} \mathrm{N}\right.$, $088^{\circ} 26^{\prime} 29^{\prime \prime}$ ), S.K.Sarkar leg., 23.IX.2018, KUZEN
S0220-S0223 (4). India, West Bengal, Nadia, Chapra $\left(23^{\circ} 30^{\prime} 38^{\prime \prime} \mathrm{N}, 088^{\circ} 33^{\prime} 08^{\prime \prime} \mathrm{E}\right)$, B.P.Kharel leg., 24.X.2018, KUZEN S0224 (19). India, West Bengal, Nadia, Tehatta $\left(23^{\circ} 43^{\prime} 46^{\prime \prime} \mathrm{N}, 088^{\circ} 31^{\prime} 56^{\prime \prime} \mathrm{E}\right)$, B.P.Kharel leg., 22.XI.2018, KUZEN S0225-S0230 (6 $\left.{ }^{\AA}\right)$. India, West Bengal, Nadia, Chakdaha $\left(23^{\circ} 04^{\prime} 46^{\prime \prime} \mathrm{N}, 088^{\circ} 30^{\prime} 56^{\prime \prime} \mathrm{E}\right)$, S.K.Sarkar leg., 10.II.2019, KUZEN S0231-S0232 (2ठ).

Identification $(\delta)$. This species can be distinguished from other Onthophagus species by the head subcircular, with angulate sides; clypeus rugose, with a pair of erect horns upon the fronto-clypeal suture; clypeal margin reflexed; pronotum densely punctate, anteriorly declivous and posteriorly slightly margined; elytra strongly striate, with interstriae flat and coarsely punctate; pygidium finely and sparsely punctate.

Geographical distribution. Australia, China, Indonesia, Malaysia, Myanmar, Nepal, and United States of America (Arrow 1931; Biswas and Chatterjee 1986a; Sewak 2009b). India: Arunachal Pradesh, Chhattisgarh, Madhya Pradesh, Odisha, Rajasthan, Tripura, Uttarakhand, Uttar Pradesh, and West Bengal (Arrow 1931; Biswas and Chatterjee 1986a, 1986b, 1991; Chatterjee and Biswas 2000; Chandra 2000; Chandra and Ahirwar 2005a, 2005b, 2007; Sewak 2006, 2009b; Chandra and Gupta 2012c, 2012d, 2013; Gajendra and Prasad 2016).

Remarks. This species is widely distributed throughout the country.

\section{Onthophagus (Eremonthophagus) semicinctus d'Orbigny, 1897}

Figure 4E

Material examined (1 $\left.{ }^{\circ}\right)$. India, West Bengal, Nadia, Chapra $\left(23^{\circ} 30^{\prime} 51^{\prime \prime} \mathrm{N}, 088^{\circ} 33^{\prime} 08^{\prime \prime} \mathrm{E}\right)$, B.P.Kharel leg., 23. IX.2017, KUZEN S0233 (1ㅇ).

Identification ( + ). This species can be distinguished from other Onthophagus species by the head broad, with small rudimentary horns on the vertex and a transverse and medially projected carina on the forehead; clypeus transversely rugose, with a curved carina separating it from the forehead; clypeal margin sinuous and feebly excised medially; pronotum finely and coarsely punctate, with anterior angles bluntly produced, and anterior margin rounded; elytra finely striate, with flat interstriae; pygidium sparsely punctate.

Geographical distribution. Pakistan (Arrow 1931). India: Gujarat, Karnataka, Maharashtra, Rajasthan, and Uttar Pradesh (Arrow 1931; Sewak 2009a, 2009b, 2010; Karimbumkara and Priyadarsanan 2013).

Remarks. This species is a new record for West Bengal state.

\section{Onthophagus (Onthophagus) socialis Arrow, 1931}

Figure 4F

Material examined (1 9 ). India, West Bengal, Santipur $\left(23^{\circ} 15^{\prime} 57^{\prime \prime} \mathrm{N}, 088^{\circ} 26^{\prime} 29^{\prime \prime} \mathrm{E}\right)$, B.P.Kharel leg., 23.VIII. 2018, KUZEN S0234 (1우). 
Identification (O). This species can be distinguished from other Onthophagus species by the head broad, strongly rounded laterally, with a straight carina on vertex; clypeus rugose, anteriorly rounded, with a strong carina separating it from the forehead; pronotum strongly punctate, with a pair of prominences behind the front margin, anterior angles blunt; elytra deeply striate, with convex interstriae; metaventrite coarsely punctate.

Geographical distribution. India: Maharashtra, Karnataka, and Tamil Nadu (Arrow 1931; Chandra 2005; Karimbumkara and Priyadarsanan 2013).

Remarks. This species is newly recorded for West Bengal state.

\section{Onthophagus (Colobonthophagus) triceratops Arrow, 1913}

Figure 4G

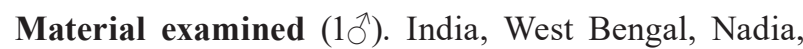
Nakashipara $\left(23^{\circ} 35^{\prime} 34^{\prime \prime} N, 088^{\circ} 20^{\prime} 55^{\prime \prime} E\right)$, S.K. Sarkar leg., 11.IX.2018, KUZEN S0235 (1ठ̋).

Identification $(\circlearrowleft)$. This species can be distinguished from other Onthophagus species by the broad head, which is angularly dilated above eyes and with a pair of strongly curved and convergent horns on the vertex, the base of which is flat and plate like; clypeus truncate, with a feeble straight carina separating it from the forehead, clypeal margin strongly reflexed; pronotum minutely and sparsely punctate, with anterior angles pointed and posteriorly slightly rounded; metaventrite coarsely punctate laterally.

Geographical distribution. India: Arunachal Pradesh, Assam, Gujarat, Karnataka, Rajasthan, Tripura, and West Bengal (Arrow 1931; Biswas and Chatterjee 1985, 1986a; Chatterjee and Biswas 2000; Sewak 2006, 2009a; Karimbumkara and Priyadarsanan 2013; Sarkar et al. 2015).

Remarks. This species is widely distributed throughout the country.

\section{Onthophagus (Indonthophagus) turbatus Walker, 1858}

Figure $4 \mathrm{H}$

Material examined (1ㅇ). India, West Bengal, Nadia, Chakdaha $\left(23^{\circ} 04^{\prime} 41^{\prime \prime} \mathrm{N}, 088^{\circ} 31^{\prime} 05^{\prime \prime} \mathrm{E}\right)$, B.P.Kharel leg., 10.XI.2018, KUZEN S0236 (1ㅇ).

Identification ( $\odot$ ). It can be distinguished from other Onthophagus species by the broad head, with a transverse and strongly elevated carina on the vertex; clypeus coarsely punctate, with a curved carina separating it from the forehead; pronotum finely and closely punctate, with the anterior margin medially elevated and with a pair of prominences on each side of the upper edge; pygidium finely punctate.

Geographical distribution. China, Myanmar, Sri Lanka, Thailand, and Vietnam (Karimbumkara and Priyadarsanan 2013; Schoolmeesters 2019). India:
Karnataka, Kerala, Maharashtra, Odisha, Puducherry, and Tamil Nadu (Arrow 1931; AnithaRani and Sanjayan2013; Karimbumkara and Priyadarsanan 2013; Sathiandran et al. 2015; Schoolmeesters 2019).

Remarks. This species is newly recorded for West Bengal state.

\section{Onthophagus (Onthophagus) zebra Arrow, 1931}

Figure 4I

Material examined (1). India, West Bengal, Chapra $\left(23^{\circ} 30^{\prime} 47^{\prime \prime} \mathrm{N}, 088^{\circ} 33^{\prime} 12^{\prime \prime} \mathrm{E}\right)$, S.K.Sarkar leg., 11.IX.2018, KUZEN S0237 (1우).

Identification ( + ). This species can be distinguished from other Onthophagus species by the narrow head, with a straight carina on the vertex; clypeus coarsely punctate, with a rounded carina separating it from the forehead; pronotum finely and densely punctate, with a broad prominence just behind the anterior margin; elytra longitudinally striped; metaventrite finely and sparsely punctate.

Geographical distribution. India: Madhya Pradesh, Maharashtra, and Karnataka (Arrow 1931; Chandra 2000; Chandra and Ahirwar2007; Jadhav and Sharma 2012; Chandra and Gupta 2012c, 2012d; Karimbumkara and Priyadarsanan 2013).

Remarks. This species is newly recorded for West Bengal state.

\section{Discussion}

The faunistic survey of the dung beetle fauna of the Nadia district of the Indian West Bengal state found approximately 78 species, of which 22 belong to the genus Onthophagus. All the species of Onthophagus reported here are new records for Nadia district, and 12 of them are newly reported for the state of West Bengal: $O$. (O.) andrewesi, O. (O.) ceylonicus, O. (Onthophagiellus) crassicollis, O. (Colobonthophagus) hindu, O. (O.) mauritii, O. (Colobonthophagus) paliceps, O. (Colobonthophagus) pardalis, O.(O.) porcus, O. (Eremonthophagus) semicinctus, O. (O.) socialis, O. (Indonthophagus) turbatus, and $O$. (O.) zebra. Among all recorded species, $O$. (Colobonthophagus) dama seems to be the dominant species as it is the most abundant and more widely distributed species throughout the studied area followed by O. (Serrophorus) sagittarius.

We also compiled a preliminary checklist of Indian Ontophagus by gathering geographic data from past literature and labels of reference specimens deposited in the ZSI (Appendix, Table A1). Until now, a total of 190 species are known to occur across India. Of these, $O$. (Colobonthophagus) ramosellus shows widest distribution throughout the country as it is reported from maximum number of states and union territories (17) of India followed by $O$. (Colobonthophagus) dama, O. (Colobonthophagus) ramosus, and $O$. (Colobonthophagus) quadridentatus (16 each). In turn, 44 species have so far 
been recorded specifically from West Bengal, which is about a quarter of the total species recorded from India.

Of the total 190 species presented in the India checklist, 84 are reported only from India, which means that about $44 \%$ of the Onthophagus present in the country are endemic.

\section{Acknowledgements}

We thank the honorable vice chancellor of the University of Kalyani for providing necessary laboratory facilities and sanctioning Personal Research Grant (PRG) 2018-19, DST-PURSE research grant 2018-19 to SKS, and URS fellowship to BPK for the research work. We also thank the director of the Zoological Survey of India for granting permission to study and compare the specimens kept at his institution's collection. Thanks are also extended to various researchers for literature support and preparation of the checklist from India.

\section{Authors' Contributions}

BPK and SKS collected the data, identified the specimens, and prepared the figures, including the map of the study area. BPK, PS, and SKS made the analysis, wrote the text, and prepared the checklist. All the authors checked and approved the last version of the manuscript.

\section{References}

Ali SMS, Naeem M, Baig F, Shahzad A, Zia A (2015) New records, distributional notes and species diversity of dung beetles (Coleoptera: Scarabaeidae: Scarabaeinae) from Pothohar Plateau of Punjab, Pakistan. Journal of Entomology and Zoology Studies 3 (3): $1-6$.

Anitha Rani A, Sanjayan KP (2013) Community composition of dung beetle and population dynamics of Tiniocellus spinipes in a scarab Jungle ecosystem. Asian Journal of Biological and Life Sciences 2 (3): 241-246.

Anto A, Vinod KV (2017) Succession of dung beetles (Scarabaeinae: Coleoptera) in the cow dung pats of a tropical agro habitat in Kerala, South India. IOSR Journal of Environmental Science, Toxicology and Food Technology 11 (6): 46-49. https://doi. org/10.9790/2402-1106024649

Arrow GJ (1931) The fauna of British India including Ceylon and Burma, part III, Coleoptera: Lamellicornia (Coprinae). Taylor and Francis, London, 353pp.

Arrow GJ (1933) Notes on coprid Coleoptera with descriptions of a new genus and a few new species. The Annals and Magazine of natural History, including Zoology, Botany and Geology, London (Series 10) 12: 421-430. https://doi.org/10.1080/00222933308673705

Balthasar V (1933) Neue Coprohagen-Artenaus British-Indien und Indochina. Časopis Československé Společnosti Entomologické, Praha 30: 45-51.

Balthasar V (1963) Monographie der Scarabaeidae and Aphodiidae der Palaearktischen und Orientalischen Region, Coleoptera: Lamellicornia, Coprinae (Onitini, Oniticellini, Onthophagini). Tschechoslowakische Akademie der Wissenschaften, Prague, 137226.

Bezděk A, Hájek J (2013) Catalogue of type specimens of beetles (Coleoptera) deposited in the National Museum, Prague, Czech Republic, Scarabaeidae: Scarabaeinae: Onitini, Onthophagini,
Phanaeini, Scarabaeini and Sisyphini. Acta Entomologica Musei Nationalis Pragae 53 (1): 387-442.

Bharamal DL, Koli YJ, Korgaonkar DS, Bhawane GP (2014) Scarab (Scarabaeidae) fauna of Sindhudurg district, Maharashtra, India. Biolife 2 (4): 1301-1304.

Biswas S(1978) Studies on the scarab beetles (Coleoptera:Scarabaeidae) of north-eastern India: a new species and notes on other Indian species of subgenus Strandius, genus Onthophagus. Journal of Bombay Natural History Society 75 (3): 911-913.

Biswas S (1979) Studies on the scarab beetles (Coleoptera:Scarabaeidae) of north India, part-II: three new species and two new records from India. Journal of Bombay Natural History Society 76: 339344.

Biswas S, Chatterjee SK (1985) Insecta: Coleoptera: Scarabaeidae: Coprinae.Records of the Zoological Survey India 82 (1-4): 147177.

Biswas S, Chatterjee SK (1986a) Dung beetles fauna (Coleoptera: Scarabaeidae: Scarabainae) of Palamou Tiger Reserve, Bihar, with description of a new species. Records of the Zoological Survey of India 83 (3-4): 57-67.

Biswas S, Chatterjee SK (1986b) Scarabaeidae (India Coleoptera) of Silent Valley, Kerala, India with description of three new species. Records of the Zoological Survey of India 84 (1-4): 79-96.

Biswas S, Chatterjee SK (1991) Insecta: Coleoptera: Scarabaeidae. Fauna of Orissa, State Fauna Series, Zoological Survey of India 1 (3): 243-262.

Biswas S, Chatterjee SK, Sengupta T (1999) The Scarabaeidae of Andaman and Nicobar islands, with description of a new species. Records of Zoological Survey of India 97: 51-72.

Boucomont A (1921) Onthophages nouveaux de l'Inde [Col. Scabaeidae]. Bulletin de la Société Entomologique de France 26 (4): $44-$ 46.

Cambefort Y (1991) Biogeography and evolution. In: Hanski I, Cambefort Y (Eds) Dung beetle ecology. Princeton University Press, Princeton, 51-67.

Chandra K (2000) Inventory of scarabaeid beetles (Coleoptera) from Madhya Pradesh, India. Zoos' Print Journal 15 (11): 359-362. https://doi.org/10.11609/JoTT.ZPJ.15.11.359-62

Chandra K (2002) On a collection of scarabaeid beetles from Pench Tiger Reserve (Seoni), Madhya Pradesh. Journal of Tropical Forestry 18 (2-3): 104-107.

Chandra K (2005) Insecta: Coleoptera: Scarabaeidae. Fauna of Western Himalayas, Himachal Pradesh, Zoological Survey of India 2: $141-155$.

Chandra K (2009) Fauna of Tamil Nadu. Zoological Survey of India, State Fauna Series 17 (1): 79-89.

Chandra K, Ahirwar SC (2005a) Scarabaeid beetles of Bandhavgarh National Park, Madhya Pradesh. Zoos' Print Journal 20 (8): 19611964. https://doi.org/10.11609/JoTT.ZPJ.1281.1961-4

Chandra K, Ahirwar SC (2005b) Scarabaeid beetles (Coleoptera) of Kanha Tiger Reserve, Madhya Pradesh. Records of the Zoological Survey of India 105 (1-2): 147-155.

Chandra K, Ahirwar SC (2007) Insecta: Coleoptera: Scarabaeidae, fauna of Madhya Pradesh (including Chhattisgarh). Zoological Survey of India, State Fauna Series 15: 273-300.

Chandra K, Gupta D (2011a) Study of scarabaeid beetles (Coleoptera) of Veerangana Durgavati Wildlife Sanctuary, Damoh, Madhya Pradesh, India. Deccan Current Science 5: 272-278.

Chandra K, Gupta D (2011b) Two new records of genus Onthophagus Latreille, 1802 (Coleoptera: Scarabaeidae) from Madhya Pradesh, India. Uttar Pradesh Journal of Zoology 31 (2): 253-255.

Chandra K, Gupta D (2012a) New distributional record of five species of Onthophagus (Coleoptera: Scarabaeidae: Scarabaeinae) from central India. Scholarly Journal of Agricultural Science 2 (1): $8-12$.

Chandra K, Gupta D (2012b) Study of external male genitalia of ten species of Indian dung beetles (Coleoptera: Scarabaeidae: Scarabaeinae). International Journal of Science and Nature 3 (3): 635-638. 
Chandra K, Gupta D (2012c) An inventory of scarab beetles (Coleoptera: Scarabaeidae) of Achanakmar-Amarkantak Biosphere Reserve, Chhattisgarh, India. International Journal of Science and Nature 3 (4): 886-891.

Chandra K, Gupta D (2012d) First report on five species of genus Onthophagus Latreille, 1802 (Coleoptera, Scarabaeidae) from Madhya Pradesh, India and their description of external male genitalia. Biodiversity Journal 3 (2): 99-106.

Chandra K, Gupta D (2012e) Diversity and composition of dung beetles (Scarabaeidae: Scarabaeinae: Aphodiinae) assemblages in Singhori Wildlife Sanctury, Raisen, Madhya Pradesh (India). Munis Entomology \& Zoology 7 (2): 812-827.

Chandra K, Gupta D (2013) Taxonomic studies on dung beetles (Coleoptera: Scarabaeidae, Geotrupidae, Hybosoridae) of Chhattisgarh, India. Munis Entomology \& Zoology 8 (1): 331-360.

Chandra K, Khan S, Gupta D, Singh SP (2011) Additional records of scarab fauna (Coleoptera: Scarabaeidae) of Pachmarhi Biosphere Reserve, Madhya Pradesh, India. National Journal of Life Sciences 8 (1): 65-68.

Chandra K, Gupta D, Uniyal VP, Bharadwaj M, Sanyal AK (2012a) Studies on scarabaeid beetles (Coleoptera) of Govind Wildlife Sanctuary, Garhwal, Uttarakhand, India. Biological Forum - an International Journal 4 (1): 48-54.

Chandra K, Gupta D, Uniyal VP, Sanyal A, Bhargav V (2012b) Taxonomic studies on lamellicorn scarabaeids (Coleoptera) of Simbalbara Wildlife Sanctuary, Sirmour, Himachal Pradesh, India. Records of the Zoological Survey of India 112 (1): 81-91.

Chandra K, Khan S, Gupta D (2012c) New records to the species diversity of family Scarabaeidae and Hybosoridae (Coleoptera: Scarabaeoidea) of Jabalpur, Madhya Pradesh (India). Academic Journal of Entomology 5 (1): 28-36.

Chandra K, Singh RK (2004) On a collection of scarabaeid beetles (Coleoptera) from Pachmarhi Biosphere Reserve, Madhya Pradesh. Records of the Zoological Survey of India 102 (3-4): 43-46.

Chandra K, Singh PS (2010) Scarabaeid beetles (Coleoptera) of Achanakmar Wildlife Sanctuary, Chhattisgarh. National Journal of Life Sciences 7 (1): 71-74.

Chatterjee SK, Biswas S (2000) Insecta: Coleoptera: Scarabaeidae. Zoological Survey of India, Fauna of Tripura, State Fauna Series 7 (3): 87-98.

Davis ALV, Scholtz CH, Philips TK (2002) Historical biogeography of scarabaeine dung beetles. Journal of Biogeography 29 (9): 1217 1256 .

Endrödi S (1974) The scientific results of Dr. G. Topal's collecting in India.Nr. 5.Sammelergebnisseaus der Superfamilie Lamellicornia, Casopis Slezkehomuzea Opava 23: 1-5.

Frey G (1954) Beschreibungneuer Onthophagus-Artenaus dem Museum Frey, Zoologischen Museum Berlin und Museum Paris (coll. Oberthür). Entomologische Arbeitenaus dem Museum G. Frey Tutzingbei München 5:741-745.

Frey G (1962) Neue Onthophagus-Arten (Col. Scarab.). Entomologische Arbeitenaus dem Museum G. Frey Tutzingbei München 13: $617-618$

Frey G (1964) Ein neuer Indischer Onthophagus (Col.Copr.). Entomologische Arbeitenaus dem Museum G. Frey Tutzingbei München 15 (1): 290

Frey G (1975) Neue Onthophagenaus Südindien und Afrika (Col Scarabaeidae). Entomologische Arbeitenaus dem Museum G. Frey Tutzingbei München 26: 198.

Gaikwad AR, Bhawane GP (2016) Observation on life cycle and nesting behavior of dung beetle Onthophagus catta (Fabricius). International Journal of Zoology Studies 1 (7): 09-13.

Gajendra N, Prasad SK (2016) A Review of Coleoptera diversity of Chhattisgarh: updated checklist 2015. International Journal of Science and Research 5 (4): 710-714.

Gordon RD, Oppenheimer JR (1977) Taxonomy and ecology of two species of Indian Onthophagus. Oriental Insects 9 (4): 495-501. https://doi.org/10.1080/00305316.1975.10434516

Gupta D, Chandra K, Khan S (2014) An updated checklist of scarabaeoid beetles (Coleoptera: Scarabaeoidea) of Pench Tiger Reserve, Madhya Pradesh, India. Journal of Entomology and Zoology Studies 2 (5): 225-240.

Harold E (1859) Beitrage zur kenntnis einiger coprophagen lamellicornien (I. Stück). Berliner Entomologische Zeitschrift 3: $193-$ 224.

Huijbregts J, Krikken J (2009) Sulawesi Onthophagus with paraocular protrusions: ten new species, with a key (Coleoptera: Scarabaeidae: Scarabaeinae). Tijdschriftvoor Entomologie 152 (2): 209-236. https://doi.org/10.1163/22119434-900000278

Jadhav MJ, Sharma RM (2012) Insecta: Coleoptera: Scarabaeidae (scarabaeid beetles). Fauna of Maharashtra, State Fauna Series, Zoological Survey of India 20 (2): 489-494.

Kabakov ON (2006) A little known and new species of the tribe Onthophagini from India, Pakistan, Myanmar and China. Trudy Russkogo Entomologicheskogo Obschchestva 77: 123-131.

Kalawate AS (2018) A preliminary study on the dung beetles of the Northern Western Ghats, Maharashtra, India. Journal of Threatened Taxa 10 (2): 11316-11331. https://doi.org/10.11609/jott.3844. 10.2.11316-11331

Karimbumkara SN, Priyadarsanan DR (2013) Fauna of Karnataka, State Fauna Series. Zoological Survey of India 21: 173-178.

Karimbumkara SN, Priyadarsanan DR (2016) Report of dung beetles (Scarabaeidae: Scarabaeinae) attracted to unconventional resources, with the description of three new species. Entomon 41 (4): 265-282.

Löbl I and Löbl D (2016) Catalogue of Palaearctic Coleoptera, revised and updated edition. Vol. 3. Brill Publishers, Leiden, 983 pp.

Mittal I (1993) Natural manuring and soil conditioning by dung beetles. Tropical Ecology 34: 150-159.

Moczek A (2011) Evolution and development: Onthophagus beetles and the evolutionary developmental genetics of innovation, allometry, and plasticity. In: Simmons LW, Ridsdill-Smith TJ (Eds) Ecology and evolution of dung beetles. Blackwell Publishing, Oxford, 126-151.

Muhaimin AMD, Hazmi IR, Yaakop S (2015) Colonization of dung beetles (Coleoptera: Scarabaeidae) of smaller body size in the Bangi Forest Reserve, Selangor, Malaysia: a model sampling site for a secondary forest area. Pertanika Journal of Tropical Agricultural Science 38 (4): 519-532.

Nichols E, Spector S, Louzada J, Larsen T, Amezquita S, Favila ME (2008) Ecological functions and ecosystem services provided by Scarabaeinae dung beetles. Biological Conservation 141: 14611474. https://doi.org/10.1016/j.biocon.2008.04.011

Niino M, Hosaka T, Kon M, Ochi T, Yamada T, Okuda T (2014) Diel flight activity and habitat preference of dung beetles (Coleoptera: Scarabaeidae) in Peninsular Malaysia. Raffles Bulletin of Zoology 62: 795-804.

Nithya S, Thomas SK (2012) New species, new synonym, and redescription of Onthophagus (Coleoptera: Scarabaeidae: Scarabaeinae) from the Western Ghats, India. Zootaxa 3526: 53-58. https:// doi.org/10.11646/zootaxa.3526.1.5

Oppenheimer JR (1977) Ecology of dung beetles (Scarabaeidae: Coprinae) in two villages of West Bengal. Records of the Zoological Survey of India 72: 389-398.

Philips TK (2011) The evolutionary history and diversification of dung beetles. In: Simmons LW, Ridsdill-Smith TJ (Eds) Ecology and evolution of dung beetles. Wiley-Blackwell, Oxford, 21-46.

Philips TK (2016) Phylogeny of the Oniticellini and Onthophagini dung beetles (Scarabaeidae, Scarabaeinae) from morphological evidence. ZooKeys 579: 9-57. https://doi.org/10.3897/zookeys. 579.6183

Saha S, Raychaudhuri D (2000) Scavanger beetles (Scarabaeidae: Coprinae) of Buxa Tiger Reserve, Jalpaiguri, West Bengal. Insect Environment 6 (1): 43-44. 
Sarkar SK, Saha S, Raychaudhuri D (2010) Further additions to the scarab beetles of Buxa Tiger Reserve, Jalpaiguri, West Bengal. Bionotes 12 (4): 131-132.

Sarkar SK, Saha S, Raychaudhuri D (2015) On the taxonomy of Scarabaeine fauna (Coleoptera: Scarabaeidae) of Buxa Tiger Reserve (BTR), West Bengal, India. Munis Entomology \& Zoology 10 (1): 18-48.

Sathiandran N, Thomas KS, Flemming AT (2015) An illustrated checklist of dung beetles (Coleoptera: Scarabaeidae) from the PeriyarTiger Reserve, Kerala, India. Journal of Threatened Taxa 7 (15): 8250-8258. https://doi.org/10.11609/jott.2466.7.15.82508258

Scheuern J (1995) Taxonomie, sexual Dimorphismus und neubeschreibungen orientalischer Onthophagus-Arten unter Besonderer Berucksichtigung des Subgenus Colobonthophagus. Entomologica Basiliensia 18: 413-453.

Scheuern J (1996) Neue und verkannte Onthophagus-Artenaus Orientalischen Region. Stuttgarter Baitragezur Naturkunde Serie A (Biologie) 542: 1-20.

Schoolmeesters P (2019) Catalogue of Life: 2019 annual checklist, world Scarabaeidae database. https://www.catalogueoflife.org/ col/details/database/id/27. Accessed on: 2019-13-09.

Schoolmeesters P, Thomas SK (2006) A new Onthophagus species from Kerala, India (Coleoptera: Scarabaeidae, Scarabaeinae) Phegea 34 (2): 73-75

Sewak R (1985) On a collection of dung beetles (Coleoptera: Scarabaeidae: Coprinae) from Gujarat, India. Oikasay 2 (2): 33-35.

Sewak R (1986) On a collection of dung beetles (Coleoptera: Scarabaeidae: Coprinae) from Rajasthan, India. Oikasay 3 (1): 11-15.

Sewak R (1991) Dung beetles (Coleoptera: Scarabaeidae: Coprinae) from five districts of western Uttar Pradesh. Oikasay 8 (1-2): 2527.

Sewak R (2004a) Insecta: Coleoptera: Scarabaeidae: Coprinae (Dung beetles). Zoological Survey of India, Fauna of Gujarat, State Fauna Series 8 (2): 105-125.

Sewak R (2004b) Dung beetles (Coleoptera: Scarabaeidae: Coprinae) of India with special reference to Arunachal Pradesh, Uttar Pradesh and Rajasthan. In: Gupta RK (Ed.) Advancements in insect biodiversity. Agrobios (India) Publishers, Jodhpur, 249297.

Sewak R (2006) Coleoptera: Scarabaeidae: Coprinae (dung beetles). Zoological Survey of India, Fauna of Arunachal Pradesh, State Fauna Series 13 (2): 191-224.

Sewak R (2009a) Dung beetles (Coleoptera: Scarabaeidae: Coprinae) of Thar Desert of Gujrat. Records of the Zoological Survey of India, Occasional Paper 295: 1-48.

Sewak R (2009b) Dung beetles (Coleoptera: Scarabaeidae: Coprinae) of Rajasthan. Records of the Zoological Survey of India, Occasional Paper 296: 1-106.

Sewak R (2010) Fauna of Ranthambhore National Park, Rajasthan. Zoological Survey of India Conservation Area Series 43: 93-118.

Siddiqui H, Ahmedand Z, Khatri I (2014) Distributional notes and new records for the dung beetles (Coleoptera: Scarabaeidae: Scarabaeinae) of Pakistan. Pakistan Journal of Zoology 46 (2): 295 307.

Singh AP, Mahajan S, Uniyal VP, Mondal R (2017) First report on Scarabaeid (Coleoptera) fauna of Sahaspur, Uttarakhand. Journal of Entomology and Zoology Studies 5 (6): 17-22.

Smith BTA (2006) A review of the family-group names for the superfamily Scarabaeoidea (Coleoptera) with corrections to nomenclature and a current classification. Coleopterists Society Monograph 5: 144-204. https://doi.org/10.1649/0010-065X(2006)60[14 4:AROTFN]2.0.CO;2

Tarasov S (2010) Seven new synonyms within the genus Onthophagus (Coleoptera: Scarabaeidae) from the Oriental Region. Zootaxa 2566: 45-48. https://doi.org/10.11646/zootaxa.2566.1.4

Tarasov SI, Genier F (2015) Innovative bayesian and parsimony phylogeny of dung beetles (Coleoptera, Scarabaeidae, Scarabaeinae) enhanced by ontology-based partitioning of morphological characters. PloS ONE 10 (3): 1-86. https://doi.org/10.1371/journal. pone. 0116671

Tarasov SI, Kabakov ON (2010) Two new species of Onthophagus (Coleoptera: Scarabaeidae) from Indochina, with a discussion of some problems with the classification of Serrophorus and similar subgenera. Zootaxa 2344: 17-28. https://doi.org/10.11646/ zootaxa.2344.1.2

Tarasov SI, Solodovnikov AY (2011) Phylogenetic analyses reveal reliable morphological markers to classify mega-diversity in Onthophagini dung beetles (Coleoptera: Scarabaeidae: Scarabaeinae). Cladistics 27: 490-528. https://doi.org/10.1111/j.10960031.2011.00351.x

Thomas SK, Nithya S, Vinod KV (2011) Faunal survey, endemism and possible species loss of Scarabaeinae (Coleoptera: Scarabaeidae) in the western slopes of the moist South Western Ghats, south India. Zootaxa 2830: 29-38.http://dx.doi.org/10.11646/ zootaxa.2830.1.3

Wiedemann CRW (1823) Zweihundertneue Käfer von java, Bengalen und dem Vorgebirge der guten Hoffnung. Akademische Buchhandlung, Kiel Zoologische Magazin 2 (1): 1-133.

Yokoyama K, Kai H, Koga T, Aibe T (1991) Nitrogen mineralization and microbial populations in cow dung, dung balls and underlying soil affected by paracoprid dung beetles. Soil Biology and Biochemistry 23: 649-653. https://doi.org/10.1016/0038-0717(91) 90078-X

\section{Appendix}

Table A1. Checklist of Onthophagus species recorded until now from different regions of India. List based on published literature and examination of specimens kept at ZSI museum. The checklist contains scientific names of the species, their geographical distribution, with the references containing the distributional records.

\begin{tabular}{|c|c|c|c|c|}
\hline \multirow{2}{*}{ No. } & \multirow{2}{*}{ Species } & \multicolumn{2}{|l|}{ Distribution } & \multirow{2}{*}{ References } \\
\hline & & India & Elsewhere & \\
\hline 1 & Onthophagus abacus Boucomont, 1921 & $\begin{array}{l}\text { Haryana, Madhya Pradesh, Maharastra, Odisha, } \\
\text { Puducherry, Tamil Nadu, Uttar Pradesh, West Bengal }\end{array}$ & Bangladesh & $\begin{array}{l}\text { Boucomont 1921; Arrow 1931; Chandra and Gupta 2012a, } \\
\text { 2012d; Gupta et al. } 2014\end{array}$ \\
\hline 2 & Onthophagus abreui Arrow, 1931 & $\begin{array}{l}\text { Bihar, Chhattisgarh, Haryana, Karnataka, Kerala, } \\
\text { Madhya Pradesh, Maharashtra, Uttarakhand, } \\
\text { Uttar Pradesh }\end{array}$ & Pakistan & $\begin{array}{l}\text { Arrow 1931; Chandra 2000; Chandra and Ahirwar 2007; Chan- } \\
\text { dra et al. 2012c; Chandra and Gupta 2012c, 2012d; Chandra and } \\
\text { Gupta 2013; Karimbumkara and Priyadarsanan 2013; Gupta et } \\
\text { al. 2014; Gajendra and Prasad } 2016\end{array}$ \\
\hline 3 & $\begin{array}{l}\text { Onthophagus (Colobonthophagus) } \\
\text { aenescens (Wiedemann, 1823) }\end{array}$ & $\begin{array}{l}\text { Bihar, Himachal Pradesh, Tripura, Uttar Pradesh, } \\
\text { Uttarakhand, West Bengal }\end{array}$ & $\begin{array}{l}\text { Bangladesh, China, Ne- } \\
\text { pal, Pakistan }\end{array}$ & $\begin{array}{l}\text { Wiedemann 1823; Arrow 1931; Chatterjee and Biswas 2000; } \\
\text { Chandra 2005; Chandra et al. 2012c }\end{array}$ \\
\hline 4 & Onthophagus agaricophilus Arrow, 1931 & Uttarakhand & No record found & Arrow 1931 \\
\hline
\end{tabular}




\begin{tabular}{|c|c|c|c|c|}
\hline \multirow{2}{*}{ No. } & \multirow{2}{*}{ Species } & \multicolumn{2}{|l|}{ Distribution } & \multirow{2}{*}{ References } \\
\hline & & India & Elsewhere & \\
\hline 5 & $\begin{array}{l}\text { Onthophagus (Colobonthophagus) agnus } \\
\text { Gillet, } 1925\end{array}$ & $\begin{array}{l}\text { Chhattisgarh, Gujarat, Jharkhand, Karnataka, } \\
\text { Madhya Pradesh, Maharashtra, Odisha, Rajasthan, } \\
\text { Tamil Nadu, West Bengal }\end{array}$ & No record found & $\begin{array}{l}\text { Arrow 1931; Chandra 2000; Chandra and Ahirwar 2007; Sewak } \\
\text { 2009a, 2009b, 2010; Chandra and Gupta 2012c, 2012d; Jadhav } \\
\text { and Sharma 2012; Chandra and Gupta 2013; Karimbumkara and } \\
\text { Priyadarsanan 2013; Bharamal et al. 2014; Gupta et al. 2014; } \\
\text { Gajendra and Prasad 2016; Kalawate 2018 }\end{array}$ \\
\hline 6 & $\begin{array}{l}\text { Onthophagus (Furconthophagus) amicus } \\
\text { (Gillet, 1925) }\end{array}$ & $\begin{array}{l}\text { Assam, Karnataka, Nagaland, Sikkim, Uttarakhand, } \\
\text { West Bengal }\end{array}$ & Nepal & $\begin{array}{l}\text { Arrow 1931; AnithaRani and Sanjayan 2013; Karimbumkara and } \\
\text { Priyadarsanan } 2013\end{array}$ \\
\hline 7 & $\begin{array}{l}\text { Onthophagus amphicoma Boucomont, } \\
1914\end{array}$ & Kerala, Karnataka, Puducherry, Tamil Nadu & No record found & $\begin{array}{l}\text { Arrow 1931; Chandra 2009; Karimbumkara and Priyadarsanan } \\
\text { 2013; Sathiandran et al. } 2015\end{array}$ \\
\hline 8 & Onthophagus amphinasus Arrow, 1931 & Maharashtra, Karnataka, Kerala,Tamil Nadu & No record found & $\begin{array}{l}\text { Arrow 1931; Chandra 2009; Karimbumkara and Priyadarsanan } \\
\text { 2013; Sathiandran et al. } 2015\end{array}$ \\
\hline 9 & Onthophagus amphioxus Arrow, 1931 & Karnataka, Tamil Nadu & No record found & Arrow 1931; Karimbumkara and Priyadarsanan 2013 \\
\hline 10 & $\begin{array}{l}\text { Onthophagus (Onthophagus) andrewesi } \\
\text { Arrow, } 1931\end{array}$ & Kerala, Karnataka, Maharasthra, Tamil Nadu & No record found & $\begin{array}{l}\text { Arrow 1931; Biswas and Chatterjee 1986b; Chandra 2009; } \\
\text { Karimbumkara and Priyadarsanan 2013; Sathiandran et al. } 2015\end{array}$ \\
\hline 11 & $\begin{array}{l}\text { Onthophagus (Sunenaga) anguliceps } \\
\text { Boucomont, } 1914\end{array}$ & $\begin{array}{l}\text { Arunachal Pradesh, Assam, Meghalaya, Mizoram, } \\
\text { Sikkim, West Bengal }\end{array}$ & $\begin{array}{l}\text { Bhutan, China, Myanmar, } \\
\text { Taiwan }\end{array}$ & Arrow 1931; Balthasar 1963; Biswas and Chatterjee 1986a \\
\hline 12 & Onthophagus arboreus Arrow, 1931 & $\begin{array}{l}\text { Bihar, Karnataka, } \\
\text { Kerala, Uttarakhand }\end{array}$ & No record found & Arrow 1931; Karimbumkara and Priyadarsanan 2013, 2016 \\
\hline 13 & $\begin{array}{l}\text { Onthophagus (Colobonthophagus) } \\
\text { armatus Blanchard, } 1853\end{array}$ & $\begin{array}{l}\text { Arunachal Pradesh, Assam, Chhattisgarh, Gujarat, } \\
\text { Madhya Pradesh, Odisha, Rajasthan, Tripura }\end{array}$ & $\begin{array}{l}\text { China, Iran, Myanmar, } \\
\text { Philippines, Taiwan, } \\
\text { Vietnam }\end{array}$ & $\begin{array}{l}\text { Arrow 1931; Biswas and Chatterjee 1985; Chatterjee and Biswas } \\
\text { 2000; Sewak 2006, 2009a, 2009b; Chandra and Gupta 2012a, } \\
\text { 2013; Sarkar et al. 2015; Gajendra and Prasad } 2016\end{array}$ \\
\hline 14 & $\begin{array}{l}\text { Onthophagus arunachalensis Biswas \& } \\
\text { Chatterjee, } 1985\end{array}$ & Arunachal Pradesh & No record found & Biswas and Chatterjee 1985; Sewak 2006 \\
\hline 15 & $\begin{array}{l}\text { Onthophagus (Colobonthophagus } \\
\text { arunensis Scheuern, } 1995\end{array}$ & Sikkim & Nepal & Scheuern 1995 \\
\hline 16 & $\begin{array}{l}\text { Onthophagus (Serrophorus) atropolitus } \\
\text { D'Orbigny, } 1902\end{array}$ & $\begin{array}{l}\text { Assam, Haryana, Himachal Pradesh, Meghalaya, } \\
\text { Rajasthan, Sikkim, Uttarakhand, West Bengal, }\end{array}$ & $\begin{array}{l}\text { Myanmar, Taiwan, } \\
\text { Vietnam }\end{array}$ & $\begin{array}{l}\text { Arrow 1931; Chandra 2005; Sewak 2009a, 2009b; Chandra et } \\
\text { al. 2012c }\end{array}$ \\
\hline 17 & $\begin{array}{l}\text { Onthophagus (Sunenaga) avocetta } \\
\text { Arrow, } 1933\end{array}$ & Assam, Sikkim & $\begin{array}{l}\text { Borneo, Indonesia, Java, } \\
\text { Malaysia, Myanmar, } \\
\text { Thailand }\end{array}$ & Arrow 1933 \\
\hline 18 & $\begin{array}{l}\text { Onthophagus balawaicus Scheuern, } \\
1995\end{array}$ & West Bengal & Nepal & Scheuern 1995 \\
\hline 19 & Onthophagus beesoni Arrow, 1931 & Bihar, Uttarakhand, West Bengal & Bangladesh & Arrow 1931 \\
\hline 20 & $\begin{array}{l}\text { Onthophagus (Colobonthophagus) } \\
\text { bengalensis Harold, } 1886\end{array}$ & $\begin{array}{l}\text { Haryana, Karnataka, Madhya Pradesh, } \\
\text { Rajasthan,Tamil Nadu, Uttarakhand }\end{array}$ & No record found & $\begin{array}{l}\text { Arrow 1931; Chandra 2005; Sewak 2009a, 2009b; Chandra and } \\
\text { Gupta 2011a, 2012c, 2012d; Chandra et al. 2012c; Karimbum- } \\
\text { kara and Priyadarsanan 2013; Gupta et al. } 2014\end{array}$ \\
\hline 21 & $\begin{array}{l}\text { Onthophagus bengali Gordon \& } \\
\text { Oppenheimer, } 1977\end{array}$ & Arunachal Pradesh, West Bengal & No record found & $\begin{array}{l}\text { Gordon and Oppenheimer 1977; Biswas and Chatterjee 1985; } \\
\text { Sewak } 2006\end{array}$ \\
\hline 22 & $\begin{array}{l}\text { Onthophagus (Paraphanaeomorphus) } \\
\text { bifasciatus (Fabricius, 1781) }\end{array}$ & $\begin{array}{l}\text { Assam, Bihar, Haryana, Jharkand, Karnataka, } \\
\text { Kerala, Maharasthra, Meghalaya, Sikkim, Tamil } \\
\text { Nadu, Uttarakhand, West Bengal }\end{array}$ & Myanmar, Nepal & $\begin{array}{l}\text { Arrow 1931; Gordon and Oppenheimer 1977; 0ppenheimer } \\
\text { 1977; Biswas and Chatterjee 1986b; Chandra 2009; Chandra et } \\
\text { al. 2012c; Karimbumkara and Priyadarsanan 2013; Sathiandran } \\
\text { et al. 2015; Anto and Vinod } 2017\end{array}$ \\
\hline 23 & Onthophagus bisectus Arrow, 1931 & Tamil Nadu & No record found & Arrow 1931; Chandra 2009 \\
\hline 24 & $\begin{array}{l}\text { Onthophagus (Colobonthophagus) bison } \\
\text { Boucomont, } 1919\end{array}$ & Arunachal Pradesh, West Bengal & Myanmar, Thailand & $\begin{array}{l}\text { Arrow 1931; Sewak 2006; Sarkar et al. 2015; Schoolmeesters } \\
2019\end{array}$ \\
\hline 25 & Onthophagus brevicollis Arrow, 1907 & $\begin{array}{l}\text { Chhatisgarh, Madhya Pradesh, Karnataka,Tamil } \\
\text { Nadu, }\end{array}$ & No record found & $\begin{array}{l}\text { Arrow 1931; Chandra 2000, 2009; Chandra and Ahirwar 2007; } \\
\text { Chandra and Gupta 2012c, 2012d; Karimbumkara and Priya- } \\
\text { darsanan } 2013\end{array}$ \\
\hline 26 & Onthophagus bronzeus Arrow, 1907 & Karnataka, Kerala, Maharashtra, Tamil Nadu & No record found & $\begin{array}{l}\text { Arrow 1931; Biswas and Chatterjee 1991; Chandra 2009; Karim- } \\
\text { bumkara and Priyadarsanan 2013; Sathiandran et al. } 2015\end{array}$ \\
\hline 27 & Onthophagus brutus Arrow, 1931 & Kerala, West Bengal & $\begin{array}{l}\text { Bangladesh, China, } \\
\text { Myanmar, Thailand }\end{array}$ & Arrow 1931; Thomas et al. 2011; Schoolmeesters 2019 \\
\hline 28 & $\begin{array}{l}\text { Onthophagus caesariatus Boucomont, } \\
1921\end{array}$ & Kerala & No record found & Arrow 1931; Thomas et al. 2011 \\
\hline 29 & $\begin{array}{l}\text { Onthophagus (Paraphanaeomorphus) } \\
\text { carinensis Boucomont, } 1914\end{array}$ & Rajasthan & China, Myanmar & Arrow 1931; Sewak 2009a, 2009b \\
\hline 30 & Onthophagus castetsi Lansberge, 1887 & Kerala, Tamil Nadu, Uttar Pradesh & No record found & $\begin{array}{l}\text { Arrow 1931; Biswas and Chatterjee 1986b; Chandra 2009; } \\
\text { Sathiandran et al. } 2015\end{array}$ \\
\hline 31 & $\begin{array}{l}\text { Onthophagus (Micronthophagus) cavia } \\
\text { Boucomont, } 1914\end{array}$ & Karnataka, Kerala, Maharastra, Tamil Nadu & No record found & $\begin{array}{l}\text { Arrow 1931; Karimbumkara and Priyadarsanan 2013, 2016; } \\
\text { Sathiandran et al. } 2015\end{array}$ \\
\hline 32 & $\begin{array}{l}\text { Onthophagus centricornis (Fabricius, } \\
\text { 1798) }\end{array}$ & $\begin{array}{l}\text { Arunachal Pradesh, Bihar, Haryana, Himachal } \\
\text { Pradesh, Karnataka, Kerala, Madhya Pradesh, } \\
\text { Maharashtra, Rajasthan, Tamil Nadu, Uttarkhand }\end{array}$ & $\begin{array}{l}\text { Afghanistan, Japan, } \\
\text { Myanmar, Pakistan, } \\
\text { Sri Lanka }\end{array}$ & $\begin{array}{l}\text { Arrow 1931; Biswas and Chatterjee 1985, 1986a; Chandra 2000, } \\
\text { 2005; Chandra and Ahirwar 2007; Chandra et al. 2012c; Chandra } \\
\text { and Gupta 2012d; AnithaRani and Sanjayan 2013; Karimbum- } \\
\text { kara and Priyadarsanan 2013, 2016; Schoolmeesters } 2019\end{array}$ \\
\hline 33 & $\begin{array}{l}\text { Onthophagus (Onthophagus) cervus } \\
\text { (Fabricius, 1798) }\end{array}$ & $\begin{array}{l}\text { Andaman and Nicobar Islands, Arunachal Pradesh, } \\
\text { Chhattisgarh, Gujarat, Karnataka, Kerala, Madhya } \\
\text { Pradesh, Maharashtra, Puducherry, Rajasthan, } \\
\text { Tamil Nadu, Uttarakhand, Uttar Pradesh, West } \\
\text { Bengal }\end{array}$ & $\begin{array}{l}\text { Pakistan, South Arabia, } \\
\text { Sri Lanka, Vietnam }\end{array}$ & $\begin{array}{l}\text { Arrow 1931; Biswas and Chatterjee 1986a; Chandra 2000; } \\
\text { Chandra and Ahirwar 2005a, 2005b, 2007; Sewak 2006, 2009a, } \\
\text { 2009b, 2010; Jadhav and Sharma 2012; Chandra et al. 2012b; } \\
\text { Chandra and Gupta 2012c, 2012d, 2013; AnithaRani and San- } \\
\text { jayan 2013; Karimbumkara and Priyadarsanan 2013, 2016; } \\
\text { Sathiandran et al. 2015; Gajendra and Prasad 2016; }\end{array}$ \\
\hline
\end{tabular}




\begin{tabular}{|c|c|c|c|}
\hline \multirow{2}{*}{ No. } & \multirow{2}{*}{ Species } & \multicolumn{2}{|l|}{ Distribution } \\
\hline & & India & Elsewhere \\
\hline 34 & $\begin{array}{l}\text { Onthophagus (Onthophagus) ceylonicus } \\
\text { Harold, } 1859\end{array}$ & Karnataka, Rajasthan, West Bengal & Sri Lanka \\
\hline 35 & Onthophagus chrysurus Arrow, 1931 & Assam, Karnataka & No record found \\
\hline 36 & $\begin{array}{l}\text { Onthophagus (Onthophagus) circulifer } \\
\text { Arrow, } 1931\end{array}$ & $\begin{array}{l}\text { Assam, Haryana, Jammu and Kashmir, } \\
\text { Maharasthra, Meghalaya, Punjab, Sikkim, Uttara- } \\
\text { khand, Uttar Pradesh, West Bengal }\end{array}$ & Myanmar \\
\hline 37 & Onthophagus coeruleicollis Arrow, 1917 & $\begin{array}{l}\text { Andrhra Pradesh, Karnataka, Madhya Pradesh, } \\
\text { Maharashtra, Odisha }\end{array}$ & No record found \\
\hline 38 & $\begin{array}{l}\text { Onthophagus cognatus Boucomont, } \\
1921\end{array}$ & Arunachal Pradesh, Assam, Manipur & Laos, Myanmar, Thaila \\
\hline 39 & $\begin{array}{l}\text { Onthophagus (Paraphanaeomorphus) } \\
\text { comottoi Lansberge, } 1885\end{array}$ & Karnataka & Myanmar \\
\hline 40 & Onthophagus compactus Arrow, 1933 & Haryana, Uttarakhand & No record found \\
\hline 41 & $\begin{array}{l}\text { Onthophagus (Altonthophagus) concolor } \\
\text { Sharp, } 1878\end{array}$ & $\begin{array}{l}\text { Himachal Pradesh, Jammu and Kashmir, Punjab, } \\
\text { Rajasthan, Uttarakhand }\end{array}$ & Afghanistan, Pakistar \\
\hline 42 & $\begin{array}{l}\text { Onthophagus (Palaeonthophagus) } \\
\text { conspersus Reitter, } 1892\end{array}$ & Jammu and Kashmir & $\begin{array}{l}\text { Afghanistan, } \\
\text { Azerbaijan, Iran, Tajik } \\
\text { stan, Turkmenistan }\end{array}$ \\
\hline 43 & Onthophagus coorgensis Arrow, 1931 & Karnataka, Kerala, Tamil Nadu & No record found \\
\hline 44 & $\begin{array}{l}\text { Onthophagus (Onthophagiellus) } \\
\text { crassicollis Boucomont, } 1913\end{array}$ & Arunachal Pradesh, Rajasthan & $\begin{array}{l}\text { China, Iran, Malaysia, } \\
\text { Myanmar, Thailand, } \\
\text { Vietnam }\end{array}$ \\
\hline 45 & $\begin{array}{l}\text { Onthophagus (Altonthophagus) } \\
\text { cupreiceps Arrow, } 1907\end{array}$ & Sikkim & Bhutan, China, Nepal \\
\hline 46 & $\begin{array}{l}\text { Onthophagus (Colobonthophagus) dama } \\
\text { (Fabricius, 1798) }\end{array}$ & $\begin{array}{l}\text { Arunachal Pradesh, Bihar, Chhattisgarh, Haryana, } \\
\text { Himachal Pradesh, Karnataka, Kerala, Madhya } \\
\text { Pradesh, Maharashtra, Odisha, Sikkim, Tamil Nadu, } \\
\text { Uttarakhand, Uttar Pradesh, West Bengal }\end{array}$ & $\begin{array}{l}\text { Bhutan, China, Nepal, } \\
\text { Sri Lanka }\end{array}$ \\
\hline
\end{tabular}

47 Onthophagus deccanensis Frey, 1962

48 Onthophagus deflexicollis Lansberge, 1883

49 Onthophagus devagiriensis Schoolmeesters \& Thomas, 2006

50 Onthophagus (Sunenaga) digitatus Arrow, 1931

51 Onthophagus (Gibbonthophagus) dubernardi Boucomont,1914

52 Onthophagus (Gibbonthophagus) duporti Boucomont, 1914

53 Onthophagus (Trichonthophagus) dynastoides Arrow, 1931

54 Onthophagus elongatus Frey, 1954

55 Onthophagus (Indonthophagus) ensifer Boucamont, 1914

56 Onthophagus (Colobonthophagus) ephippioderus Arrow, 1907

57 Onthophagus expansicornis Bates, 1891

58 Onthophagus exquisitus Arrow, 1931

59 Onthophagus falcifer Harold, 1880

60 Onthophagus falsusGillet, 1925

61 Onthophagus fasciatus Boucomont, 1924 Himachal Pradesh, Karnataka, Kerala, Madhya Pradesh, Tamil Nadu, Tripura, Uttarakhand, West Bengal

Arunachal Pradesh, Assam, Kerala, Madhya $\quad$ No record found Vietnam

Kerala No record found

Rajasthan, Sikkim

No record found

Himachal Pradesh, Karnataka, Sikkim, West Bengal, China, Myanmar, Vietnam, $\begin{array}{ll}\text { Arunachal Pradesh, Bihar, Haryana, Himachal China, Laos, Myanmar, } \\ \text { Pradesh, Karnataka, Kerala, Madhya Pradesh,Tamil } & \text { Thailand, Vietnam }\end{array}$ Nadu, Uttarakhand, Uttar Pradesh, West Bengal

Gujrat, Rajasthan

Sri Lanka

Kerala,Tamil Nadu

No record found

Andhra Pradesh, Arunachal Pradesh, Bihar, Gujarat, Pakistan Karnataka, Kerala, Rajasthan, Tamil Nadu, Uttar Pradesh

Gujarat, Karnataka, Kerala, Maharastra, Rajasthan, No record found Tamil Nadu

Himachal Pradesh, Punjab, Uttarakhand

Uttarakhand, West Bengal

Karnataka, Sikkim, West Bengal

Afghanistan

Bangladesh

No record found

Arunachal Pradesh, Gujarat, Haryana, Himachal Pradesh, Jammu and Kashmir, Karnataka, Kerala, Meghalaya, Punjab, Rajasthan, Uttarakhand Uttar Pradesh

Afghanistan, Bangladesh, Kenya, Pakistan

Bangladesh

\section{References}

Harold 1859; Arrow 1931; Sewak 2006, 2009a

Arrow 1931; Karimbumkara and Priyadarsanan 2013

Arrow 1931; Chandra et al. 2012a, 2012c; Karimbumkara and Priyadarsanan 2013, 2016

Arrow 1931; Biswas and Chatterjee 1991; Jadhav and Sharma 2012; Karimbumkara and Priyadarsanan 2013, 2016; Gupta et al. 2014

Biswas and Chatterjee 1985; Sewak 2006; Tarasov 2010

Arrow 1931; Karimbumkara and Priyadarsanan 2013

Chandra et al. 2012a, 2012c

Arrow 1931; Chandra 2009; Sewak 2009a, 2009b

Bezdĕk and Hájek 2013; Löbl and Löbl 2016

Arrow 1931

Arrow 1931; Biswas and Chatterjee 1985; Sewak 2006, 2009a 2009b; Muhaimin et al. 2015; Schoolmeeters 2019

Arrow 1931

Arrow 1931; Biswas and Chatterjee 1985, 1986a, 1991; Chandra 2000, 2005; Chandra and Ahirwar 2005a, 2005b, 2007; Sewak 2006; Chandra and Gupta 2011a, 2012c, 2012d, 2012e, 2013; Jadhav and Sharma 2012; Chandra et al. 2012a, 2012b, 2012c; AnithaRani and Sanjayan 2013; Karimbumkara and Priyadarsanan 2013, 2016; Bharmal et al. 2014; Gupta et al. 2014; Sarkar et al. 2015; Sathiandran et al. 2015; Gajendra and Prasad 2016; Singh et al. 2017; Kalawate 2018

Frey 1962

Pradesh, Odisha, Sikkim, Uttarakhand, West Bengal Indonesia, Laos, Myanmar, Malaysia, Thailand,

Arrow 1931; Biswas and Chatterjee 1985; Sewak 2006; Chandra and Ahirwar 2007; Sathiandran et al. 2015

Schoolmeesters and Thomas 2006

Arrow 1931; Sewak 2009a, 2009b

Arrow 1931; Chandra 2005; Sewak 2005; Karimbumkara and Priyadarsanan 2013

Arrow 1931; Biswas and Chatterjee 1985; Chandra 2005, 2009; Sewak 2006; Chandra et al. 2012c; Chandra and Gupta 2012d, 2012e; Karimbumkara and Priyadarsanan 2013, 2016; Sathiandran et al. 2015; Schoolmeeters 2019

Arrow 1931; Sewak 2009a, 2009b

Frey 1954; Thomas et al. 2011

Arrow 1931; Biswas and Chatterjee 1986a, 1986b; Sewak 2006;2009a, 2009b, 2010; Chandra 2009; AnithaRani and Sanjayan 2013; Karimbumkara and Priyadarsanan 2013, 2016; Sathiandran et al. 2015; Anto and Vinod 2017

Arrow 1931; Chandra 2009; Sewak 2009a and b; Karimbumkara and Priyadarsanan 2013

Arrow 1931; Chandra 2005; Chandra et al. 2012a, $2012 c$

Arrow 1931; Schoolmeesters 2019

Arrow 1931; Karimbumkara and Priyadarsanan 2013; Sarkar et al. 2015

Arrow 1931; Chandra 2005; Sewak 2009a, 2009b Chandra et al. 2012a, 2012c; Karimbumkara and Priyadarsanan 2013; Anto and Vinod 2017

Arrow 1931; Biswas and Chatterjee 1986b; Chatterjee and Biswas 2000; Chandra 2000, 2005, 2009; Chandra and Ahirwar 2005a, 2007; Chandra and Gupta 2012d; Karimbumkara and Priyadarsanan 2013, 2016; Sathiandran et al. 2015 


\begin{tabular}{|c|c|c|c|c|}
\hline \multirow{2}{*}{ No. } & \multirow{2}{*}{ Species } & \multicolumn{2}{|l|}{ Distribution } & \multirow{2}{*}{ References } \\
\hline & & India & Elsewhere & \\
\hline 62 & Onthophagus favrei Boucomont, 1914 & Karnataka, Kerala, Maharastra, Tamil Nadu & Sri Lanka & $\begin{array}{l}\text { Anitha Rani and Sanjayan 2013; Arrow 1931; Chandra 2009; } \\
\text { Karimbumkara and Priyadarsanan 2013;Sathiandran et al. } 2015\end{array}$ \\
\hline 63 & Onthophagus felix Arrow, 1931 & Jharkhand & No record found & Arrow 1931 \\
\hline 64 & $\begin{array}{l}\text { Onthophagus (Matashia) fossorArrow, } \\
1931\end{array}$ & Sikkim & Malaysia & Arrow 1931 \\
\hline 65 & $\begin{array}{l}\text { Onthophagus frankenbergeri Balthasar, } \\
1933\end{array}$ & Puducherry, Tamil Nadu & No record found & Balthasar 1933; Bezdĕk and Hájek 2013 \\
\hline 66 & $\begin{array}{l}\text { Onthophagus (Paraphanaeomorphus) } \\
\text { frugivorus Arrow, } 1931\end{array}$ & $\begin{array}{l}\text { Assam, Gujarat, Karnataka, Meghalaya, Sikkim, } \\
\text { Rajasthan }\end{array}$ & Myanmar, Vietnam & $\begin{array}{l}\text { Arrow 1931; Chandra 2005; Sewak 2009a, 2009b; Karimbum- } \\
\text { kara and Priyadarsanan 2013, } 2016\end{array}$ \\
\hline 67 & Onthophagus furcicollis Arrow, 1931 & $\begin{array}{l}\text { Arunachal Pradesh, Assam, Haryana, Himachal } \\
\text { Pradesh, Rajasthan, Sikkim, Uttarakhand, West } \\
\text { Bengal }\end{array}$ & Bhutan, Nepal & $\begin{array}{l}\text { Arrow 1931; Biswas and Chatterjee 1985; Chandra 2005; Sewak } \\
\text { 2006, 2009a, 2009b; Chandra et al. 2012c; Karimbumkara and } \\
\text { Priyadarsanan } 2016\end{array}$ \\
\hline 68 & Onthophagus furcillifer Bates, 1891 & $\begin{array}{l}\text { Assam, Bihar, Chhattisgarh, Haryana, Himachal } \\
\text { Pradesh, Karnataka, Kaschmir, Kerala, Madhya } \\
\text { Pradesh, Punjab, Uttarakhand, Uttar Pradesh }\end{array}$ & Nepal & $\begin{array}{l}\text { Arrow 1931; Biswas and Chatterjee 1986a; Chandra 2000, 2005; } \\
\text { Chandra and Ahirwar 2007; Chandra et al. 2012c; Karimbum- } \\
\text { kara and Priyadarsanan 2013; Sathiandran et al. 2015; Anto } \\
\text { and Vinod } 2017\end{array}$ \\
\hline 69 & Onthophagus furculus (Fabricius, 1798) & Odisha, Puducherry & Sri Lanka & Arrow 1931; Biswas and Chatterjee 1991; \\
\hline 70 & $\begin{array}{l}\text { Onthophagus fuscopunctatus (Fabricius, } \\
\text { 1798) }\end{array}$ & Gujarat, Rajasthan, Tamil Nadu & Sri Lanka & Arrow 1931; Chandra 2009; Sewak 2009a, 2009b \\
\hline 71 & $\begin{array}{l}\text { Onthophagus (Paraphanaeomorphus) } \\
\text { gagates Hope, } 1831\end{array}$ & $\begin{array}{l}\text { Arunachal Pradesh, Assam, Himachal Pradesh, } \\
\text { Manipur, Meghalaya, Punjab, Uttarakhand, Uttar } \\
\text { Pradesh, West Bengal }\end{array}$ & $\begin{array}{l}\text { Bhutan, China, Nepal, } \\
\text { Taiwan, Vietnam }\end{array}$ & $\begin{array}{l}\text { Arrow 1931; Chandra 2005; Chandra et al. 2012a, 2012b, 2012c; } \\
\text { Chandra and Gupta 2012b; Schoolmeesters } 2019\end{array}$ \\
\hline 72 & $\begin{array}{l}\text { Onthophagus (Paraphanaeomorphus) } \\
\text { gagatoides Kabakov, } 2006\end{array}$ & Himachal Pradesh, Uttarakhand & No record found & Kabakov 2006 \\
\hline 73 & Onthophagus gangeticus Gillet, 1925 & Bihar, West Bengal & Bangladesh & Arrow 1931; Schoolmeesters 2019 \\
\hline 74 & Onthophagus gemma (Sharp, 1875) & Tamil Nadu, West Bengal & SriLanka & Arrow 1931; Chandra 2009 \\
\hline 75 & Onthophagus germanus Gillet, 1927 & Sikkim, Uttarakhand, West Bengal, & No record found & Arrow 1931 \\
\hline 76 & $\begin{array}{l}\text { Onthophagus gracilipes Boucomont, } \\
1914\end{array}$ & Karnataka & $\begin{array}{l}\text { China, Myanmar, } \\
\text { Vietnam, }\end{array}$ & Karimbumkara and Priyadarsanan 2013 \\
\hline 77 & Onthophagus gratus Arrow, 1931 & $\begin{array}{l}\text { Bihar, Chhattisgarh, Himachal pradesh, Jharkhand, } \\
\text { Karnataka, Madhya Pradesh, Tamil Nadu, } \\
\text { Uttarakhand }\end{array}$ & No record found & $\begin{array}{l}\text { Arrow 1931; Chandra and Gupta 2012a, 2012d; Chandra et al. } \\
\text { 2012c; }\end{array}$ \\
\hline 78 & Onthophagus griseosetosus Arrow, 1931 & $\begin{array}{l}\text { Chhattisgarh, Himachal Pradesh, Karnataka, } \\
\text { Madhya Pradesh, Maharashtra,Tamil Nadu, } \\
\text { Uttarakhand }\end{array}$ & No record found & $\begin{array}{l}\text { Arrow 1931; Chandra 2000; Chandra and Ahirwar 2005b; } \\
\text { Jadhav and Sharma 2012; Chandra et al. 2012a, 2012b, 2012c; } \\
\text { Chandra and Gupta 2012d; Gupta et al. 2014; Karimbumkara } \\
\text { and Priyadarsanan } 2013\end{array}$ \\
\hline 79 & $\begin{array}{l}\text { Onthophagus (Micronthophagus) gulo } \\
\text { Arrow, } 1931\end{array}$ & $\begin{array}{l}\text { Karnataka, Madhya Pradesh, Maharasthra, } \\
\text { Rajasthan }\end{array}$ & No record found & $\begin{array}{l}\text { Arrow 1931; Chandra 2000; Chandra and Ahirwar 2007; Jadhav } \\
\text { and Sharma 2012; Karimbumkara and Priyadarsanan } 2013\end{array}$ \\
\hline 80 & Onthophagus hamaticeps Arrow, 1931 & $\begin{array}{l}\text { Arunachal Pradesh, Punjab, Rajasthan, } \\
\text { Uttarakhand }\end{array}$ & No record found & Arrow 1931; Sewak 2009a, 2009b \\
\hline 81 & Onthophagus hemipygus Frey, 1964 & Odisha & No record found & Frey 1964 \\
\hline 82 & $\begin{array}{l}\text { Onthophagus (Colobonthophagus) hindu } \\
\text { Arrow, } 1931\end{array}$ & $\begin{array}{l}\text { Andhra Pradesh, Chhattisgarh, Jammu and } \\
\text { Kashmir, Karnataka, Madhya Pradesh, Maharashtra }\end{array}$ & $\begin{array}{l}\text { Afghanistan, Pakistan, } \\
\text { Sri Lanka }\end{array}$ & $\begin{array}{l}\text { Arrow 1931; Chandra and Gupta 2011a, 2011b, 2012c, 2012d, } \\
\text { 2013; Chandra et al. 2012b; Karimbumkara and Priyadarsanan } \\
\text { 2013, 2016; Gupta et al. 2014; Siddiqui et al. 2014; Gajendra and } \\
\text { Prasad 2016; Kalawate } 2018\end{array}$ \\
\hline 83 & $\begin{array}{l}\text { Onthophagus (Paraphanaeomorphus) } \\
\text { hingstoni Arrow, } 1931\end{array}$ & Arunachal Pradesh, Sikkim & No record found & Arrow 1931; Chandra and Gupta 2012b \\
\hline 84 & $\begin{array}{l}\text { Onthophagus (Micronthophagus) hystrix } \\
\text { Boucomont, } 1914\end{array}$ & $\begin{array}{l}\text { Andhra Pradesh, Bihar, Haryana, Madhya Pradesh, } \\
\text { Maharasthra, Karnataka, Kerala, Odisha, Tamil } \\
\text { Nadu, Uttarakhand, Uttar Pradesh }\end{array}$ & Myanmar, Sri Lanka & $\begin{array}{l}\text { Arrow 1931; Biswas and Chatterjee 1991; Chandra 2000; Chan- } \\
\text { dra and Ahirwar 2007; Jadhav and Sharma 2012; Chandra et al. } \\
\text { 2012a, 2012c; Chandra and Gupta 2012c, 2012d; Karimbumkara } \\
\text { and Priyadarsanan } 2013\end{array}$ \\
\hline 85 & $\begin{array}{l}\text { Onthophagus (Paraphanaeomorphus) } \\
\text { insignicollis Frey, } 1954\end{array}$ & Jharkhand, Maharashtra & No record found & Frey 1954 \\
\hline 86 & $\begin{array}{l}\text { Onthophagus jwalae Karimbumkara \& } \\
\text { Priyadarsanan, } 2016\end{array}$ & Kerala & No record found & Karimbumkara and Priyadarsanan 2016 \\
\hline 87 & Onthophagus kanarensis Arrow, 1931 & Karnataka, Maharasthra & No record found & Arrow 1931; Karimbumkara and Priyadarsanan 2013 \\
\hline 88 & Onthophagus kapuri Endrödi, 1974 & Maharashtra & No record found & Endrödi 1974 \\
\hline 89 & $\begin{array}{l}\text { Onthophagus kashmirensis Balthasar, } \\
1966\end{array}$ & Jammu and Kashmir & No record found & Bezdĕk and Hájek 2013 \\
\hline 90 & $\begin{array}{l}\text { Onthophagus kchatriya Boucomont, } \\
1914\end{array}$ & Karnataka, Kerala, Odisha, Tamil Nadu & No record found & $\begin{array}{l}\text { Arrow 1931; Chandra 2009; Karimbumkara and Priyadarsanan } \\
\text { 2013; Sathiandran et al.2015 }\end{array}$ \\
\hline 91 & Onthophagus keralensis Frey, 1975 & Kerala & No record found & Frey 1975; Thomas et al.2011 \\
\hline 92 & Onthophagus keralicus Biswas, 1986 & Kerala & No record found & Biswas and Chatterjee 1986 \\
\hline 93 & $\begin{array}{l}\text { Onthophagus (Matashia) kuluensis } \\
\text { Bates, } 1891\end{array}$ & $\begin{array}{l}\text { Arunachal Pradesh, Gujarat, Haryana, Himachal } \\
\text { Pradesh, Jammu and Kaschmir, Punjab, Rajasthan, } \\
\text { Uttarakhand, Uttar Pradesh }\end{array}$ & China, Nepal & $\begin{array}{l}\text { Arrow 1931; Sewak 1986, 2006, 2009a, 2009b, 2010; Chandra } \\
\text { 2005; Chandra and Gupta 2012a, 2012b; Chandra et al. } 2012 c\end{array}$ \\
\hline 94 & Onlhophagus kumaonensis Arrow, 1931 & Himachal Pradesh, Punjab & No record found & Arrow 1931; Chandra 2005 \\
\hline
\end{tabular}




\begin{tabular}{|c|c|}
\hline No. & Species \\
\hline 95 & Onthophagus laborans Arrow, 1931 \\
\hline 96 & $\begin{array}{l}\text { Onthophagus laevigatus (Fabricius, } \\
\text { 1798) }\end{array}$ \\
\hline 97 & $\begin{array}{l}\text { Onthophagus (Serrophorus) Iaevis } \\
\text { Harold, } 1880\end{array}$ \\
\hline 98 & Onthophagus lapillus Arrow, 1931 \\
\hline 99 & Onthophagus lemniscatus Gillet, 1924 \\
\hline 100 & $\begin{array}{l}\text { Onthophagus (Furconthophagus) } \\
\text { lilliputanus Lansberge, } 1883\end{array}$ \\
\hline 101 & Onthophagus ludio Boucomont, 1914 \\
\hline 102 & $\begin{array}{l}\text { Onthophagus (Gibbonthophagus) } \\
\text { luridipennis Boheman, } 1858\end{array}$ \\
\hline 103 & Onthophagus madoqua Arrow, 1931 \\
\hline 104 & $\begin{array}{l}\text { Onthophagus malabarensis Boucomont } \\
1919\end{array}$ \\
\hline 105 & $\begin{array}{l}\text { Onthophagus (Macronthophagus) } \\
\text { manipurensis Arrow, } 1907\end{array}$ \\
\hline 106 & $\begin{array}{l}\text { Onthophagus (Palaeonthophagus) } \\
\text { marginalis (Gebler, 1817) }\end{array}$ \\
\hline
\end{tabular}

107 Onthophagus (Onthophagus) mauritii Boucomont, 1919

108 Onthophagus metalliceps Arrow, 1931

109 Onthophagus mirandus Arrow, 1931

110 Onthophagus (Indonthophagus) mopsus (Fabricius, 1792)

111 Onthophagus nagpurensis Arrow, 1931

112 Onthophagus(Gibbonthophagus) nasalis Arrow, 1931

113 Onthophagus necrophagus Arrow, 1931

114 Onthophagus nefarius Balthasar, 1963

115 Onthophagus negligens Walker, 1858

116 Onthophagus (Colobonthophagus) neocolobus Scheuern, 1996

117 Onthophagus nicobaricus Biswas Chatterjee \& Sengupta, 1999

118 Onthophagus (Macronthophagus) nilgirensis Gillet, 1922

119 Onthophagus (Colobonthophagus) occipitalis Lansberge, 1885

120 Onthophagus (Micronthophagus) ochreatus D'Orbigny, 1897

121 Onthophagus octogonus Frey, 1962

122 Onthophagus (Micronthophagus) oculatus Arrow, 1931

123 Onthophagus orientalis Harold, 1868
Distribution

India

Madhya Pradesh, Maharasthra, Karnataka

Elsewhere

No record found

Karnataka, 0disha

Sri Lanka

Arunachal Pradesh, Kerala, Sikkim, Uttarakhand, Uttar Pradesh, West Bengal

Haryana, Himachal Pradesh, Punjab, Sikkim,

Uttarakhand, West Bengal,

Karnataka, Kerala, Tamil Nadu

Chandigarh, Himachal Pradesh, Karnataka,

Kashmir, Odisha, Tamil Nadu, Uttarakhand

Andhra Pradesh, Chhattisgarh, Karnataka,

Maharashtra, Tamil Nadu

Arunachal Pradesh, Assam, Karnataka, Tripura, Uttarakhand, Uttar Pradesh

Gujarat, Karnataka, Kerala, Rajasthan, Tamil Nadu

Kerala, Maharashtra, Uttar Pradesh,

Arunachal Pradesh, Assam, Kerala, Manipur, Meghalaya

Chandigarh, Himachal Pradesh, Jammu and Kashmir, Uttarakhand

Arunachal Pradesh, Bihar, Karnataka, Maharastra, Tamil Nadu

Arunachal Pradesh, Bihar, Karnataka, Maharastra, Tamil Nadu

Assam, Himachal Pradesh, Punjab, Rajasthan, Uttarakhand

Bihar, Chandigarh, Himachal Pradesh, Jammu and

Kashmir, Karnataka, Madhya Pradesh, Punjab,

Rajasthan, Sikkim, Uttarakhand, Uttar Pradesh, West Bengal

Jharkhand

Haryana, Rajasthan, Uttarakhand

Uttarakhand

Jharkhand

Karnataka, Kerala, Tamil Nadu

Karnataka

Nicobar Islands

Arunachal Pradesh, Kerala, Tamil Nadu

Arunachal Pradesh, Rajasthan

Gujrat

Assam

Gujarat, Kerala, Puducherry, Rajasthan, Tamil Nadu

Arunachal Pradesh, Assam, Bihar, Chhattisgarah, Gujarat, Haryana, Madhya Pradesh, Maharashtra, Manipur, Meghalaya, Sikkim, Uttarakhand, West Bengal
China, Indonesia, Myanmar, Thailand, Vietnam No record found

No record found Myanmar, Philippines

Sri Lanka

Bangladesh, China, Indonesia, Myanmar, Philippines, Thailand Vietnam

Indonesia, Vietnam

No record found

China, Thailand, Myanmar

Afghanistan, Armenia, Australia, Bulgaria, China, Greece, Iraq, Israel, Kazkistan, Korea, Mongolia, Morocco, Portugal, Romania, Russia, Spain, Syria, Tajakistan, Turkey, Turkmenistan

No record found

No record found

No record found

Afghanistan, Pakistan

No record found

Nepal

No record found

Nepal

Sri Lanka

No record found

No record found

No record found

Myanmar, Sri Lanka

Morocco, Niger, Oman, Pakistan, Saudi Arabia, Senegal, Somalia, Sri

Lanka

No record found

Sri Lanka

Afghanistan, Bangladesh, Cambodia, China, Madagascar, Myanmar, Pakistan, Soudi Arabia, Sri Lanka, Thailand Vietnam

\section{References}

Arrow 1931; Chandra 2000; Chandra and Ahirwar 2007; Jadhav and Sharma 2012; Chandra and Gupta 2012c, 2012d, 2012e; Karimbumkara and Priyadarsanan 2013, 2016

Arrow 1931; Biswas and Chatterjee 1991; Karimbumkara and Priyadarsanan 2013

Arrow 1931; Biswas and Chatterjee 1985; Sewak 2006; Niino et al. 2014; Sathiandran et al. 2015; Schoolmeesters 2019

Arrow 1931; Chandra 2005; Sewak 2005

Arrow 1931; Karimbumkara and Priyadarsanan 2013

Arrow 1931; Chandra 2005, 2009; Sewak 2005; Karimbumkara and Priyadarsanan 2013; Niino et al. 2014

Arrow 1931; Chandra 2009; Jadhav and Sharma 2012; Chandra and Gupta 2013; Karimbumkara and Priyadarsanan 2013; Gajendra and Prasad 2016

Arrow 1931; Biswas and Chatterjee 1985; Chatterjee and Biswas 2000; Chandra 2005; Sewak 2006; Chandra et al. 2011; Karimbumkara and Priyadarsanan 2013, 2016; Schoolmeesters 2019

Arrow 1931; Chandra 2005; Sewak 2009a; Karimbumkara and Priyadarsanan 2013

Arrow 1931; Karimbumkara and Priyadarsanan 2016

Arrow 1931; Biswas and Chatterjee 1985; Sewak 2006; Sathiandran et al. 2015; Schoolmeesters 2019

Arrow 1931; Chandra 2005; Chandra et al. 2012a, $2012 c$

Arrow 1931; Biswas and Chatterjee 1985; Sewak 2006; Chandra 2009; Karimbumkara and Priyadarsanan 2013

Arrow 1931; Karimbumkara and Priyadarsanan 2013; Schoolmeesters 2019

Arrow 1931; Sewak 2009b

Arrow 1931; Chandra 2005; Chandra and Gupta 2012c, 2012d

Karimbumkara and Priyadarsanan 2013; Singh et al. 2017

Arrow 1931

Arrow 1931; Sewak 2009a, 2009b; Chandra and Gupta 2012a; Chandra et al. $2012 \mathrm{C}$

Arrow 1931

Balthasar 1963

Arrow 1931; Chandra 2005; Karimbumkara and Priyadarsanan 2013; Anto and Vinod 2017

Scheuern 1996

Biswas; Chatterjee and Sengupta 1999

Arrow 1931; Sewak 2006

Arrow 1931; Sewak 2006; Sewak 2009a, 2009b

Arrow 1931; Sewak 2009a; Schoolmeesters 2019

Frey 1962

Arrow 1931; Sewak 2009a, 2009b

Arrow 1931; Oppenheimer 1977; Biswas and Chatterjee 1985; Chandra 2000; Sewak 2006, 2009a, 2009b; Chandra and Ahirwar 2007; Jadhav and Sharma 2012; Chandra et al. 2012c; Chandra and Gupta 2012c, 2012d; Niino et al. 2014; Schoolmeesters 2019 


\begin{tabular}{|c|c|c|c|c|}
\hline \multirow{2}{*}{ No. } & \multirow{2}{*}{ Species } & \multicolumn{2}{|l|}{ Distribution } & \multirow{2}{*}{ References } \\
\hline & & India & Elsewhere & \\
\hline 124 & Onthophagus orissanus Arrow, 1931 & Bihar, Madhya Pradesh, Maharashtra, Odisha & No record found & $\begin{array}{l}\text { Arrow 1931; Biswas and Chatterjee 1991; Chandra and Ahirwar } \\
\text { 2007; Chandra and Gupta 2012c, 2012d; Gupta et al. } 2014\end{array}$ \\
\hline 125 & Onthophagus pacificus Lansberge, 1885 & $\begin{array}{l}\text { Arunachal Pradesh, Assam, Karnataka, Kerala, } \\
\text { Tamil Nadu, Uttarakhand, West Bengal }\end{array}$ & $\begin{array}{l}\text { Bangladesh, China, In- } \\
\text { donesia, Laos, Malaysia, } \\
\text { Myanmar, Thailand, } \\
\text { Vietnam }\end{array}$ & $\begin{array}{l}\text { Arrow 1931; Biswas and Chatterjee 1985; Sewak 2006; Karim- } \\
\text { bumkara and Priyadarsanan 2013; Sathiandran et al. 2015; } \\
\text { Schoolmeesters } 2019\end{array}$ \\
\hline 126 & $\begin{array}{l}\text { Onthophagus palamuoi Biswas \& } \\
\text { Chatterjee, } 1986\end{array}$ & $\begin{array}{l}\text { Bihar, Jammu and Kashmir, Maharashtra, Tamil } \\
\text { Nadu, Uttar Prrdesh, West Bengal }\end{array}$ & No record found & Biswas and Chatterjee 1986b \\
\hline
\end{tabular}
$127 \begin{aligned} & \text { Onthophagus (Colobonthophagus) Karnataka, Madhya Pradesh, Uttarakhand Pakistan } \\ & \text { paliceps Arrow, } 1931\end{aligned}$

128 Onthophagus parafasciatus Balthasar, 1974

129 Onthophagus (Colobonthophagus) pardalis Boucomont, 1914

130 Onthophagus (Furconthophagus) parvulus (Fabricius, 1798)

131 Onthophagus pauliani Balthasar, 1937

132 Onthophagus (Paraphanaeomorphus) phanaeiformis Boucomont, 1914

133 Onthophagus pithankithae Karimbumkara \& Priyadarsanan, 2016

134 Onthophagus planifrons Frey, 1962

135 Onthophagus politus (Fabricius, 1798)

136 Onthophagus pollicatus Harold, 1879

137 Onthophagus (Onthophagus porcus) Arrow, 1931

138 Onthophagus (Sinonthophagus) productus Arrow, 1907

139 Onthophagus pusillus (Fabricius, 1798)

140 Onthophagus pygmaeus (Schaller, 1783)

141 Onthophagus (Colobonthophagus) quadridentatus (Fabricius, 1798)

142 Onthophagus (Colobonthophagus) ramosellus Bates, 1891

143 Onthophagus (Colobonthophagus) ramosus (Wiedemann, 1823)

144 Onthophagus rana Arrow, 1931

145 Onthophagus(Serrophorus) rectecornutus Lansberge, 1883

146 Onthophagus refulgens Arrow, 1931

147 Onthophagus (Gibbonthophagus) remotus Harold, 1879

148 Onthophagus royi Biswas \& Chatterjee, 1985

149 Onthophagus (Macronthophagus) rubricollis Hope, 1831

150 Onthophagus rubripennis Arrow, 1907

151 Onthophagus (Sinonthophagus) rugulosus Harold, 1886

152 Onthophagus(Serrophorus) sagittarius (Fabricius, 1775)
Tamil Nadu

Karnataka, Maharashtra, Tamil Nadu

Karnataka, Maharashtra, Tamil Nadu

Meghalaya

Arunachal Pradesh

Karnataka, Kerala,

Arunachal Pradesh, Assam

Arunachal Pradesh, Bihar, Gujarat, Haryana, Himachal Pradesh, Karnataka, Rajasthan, Tamil Nadu, Uttar Pradesh

Assam

Arunachal Pradesh, Karnataka

Gujarat, Himachal Pradesh, Rajasthan, Sikkim Uttarakhand, West Bengal

Karnataka

Karnataka, Kerala

Arunachal Pradesh, Assam, Bihar, Chhattisgarh, Himachal Pradesh, Karnataka, Kerala, Madhya Pradesh, Maharashtra, Odisha, Punjab, Rajasthan, Tamil Nadu, Uttarakhand, Uttar Pradesh, West Bengal

Arunachal Pradesh, Assam, Bihar, Chhattisgarh, Haryana, Himachal Pradesh, Karnataka Madhya Pradesh, Maharashtra, Meghalaya, Odisha, Punjab, Rajasthan, Tripura, Uttarakhand, Uttar Pradesh, West Bengal

Bihar,Chhattisgarh, Gujarat, Himachal Pradesh, Jammu and Kashmir, Karnataka, Madhya Pradesh, Maharashtra, Odisha, Punjab, Rajasthan, Tamil Nadu, Uttarakhand, Uttar Pradesh

Gujarat, Karnataka, Kerala, Tamil Nadu

Arunachal Pradesh, Assam, Bihar, Karnataka, Kerala, Nagaland, Tamil Nadu, Tripura, Uttarakhand, West Bengal

Kerala, Tamil Nadu

Arunachal Pradesh

Arunachal Pradesh

Arunachal Pradesh, Himachal Pradesh, Meghalaya, Uttarakhand, Uttar Pradesh, West Bengal

Arunachal Pradesh, Assam, Sikkim, Meghalaya, West Bengal

Arunachal Pradesh, Assam, Meghalaya

Arunachal Pradesh, Chhattisgarh, Madhya Pradesh Odisha, Rajasthan, Tripura, Uttarakhand, Uttar Pradesh, West Bengal
No record found

No record found

Pakistan, Sri Lanka

No record found

Myanmar; Thailand,

Vietnam

No record found

No record found

Sri Lanka

Bangladesh, Myanmar

Bangladesh

China

Sri Lanka

Sri Lanka

Pakistan, Sri Lanka,

Taiwan

Afghanistan, Myanmar, Nepal, Pakistan

Pakistan

(2)

record found

Bangladesh, Bhutan,

Malaysia, Myanmar,

Sri Lanka, Thailand,

Vietnam

Sri Lanka

Myanmar

No record found

Bhutan, China, Myanmar, Nepal

Bhutan, Myanmar

China, Korea, Russia, Vietnam

Australia, China, Indonesia, Malaysia, Myanmar, Nepal, United States of America
Arrow 1931; Chandra and Gupta 2012c, 2012d; Karimbumkara and Priyadarsanan 2013; Siddiqui et al. 2014

Bezdĕk and Hájek 2013

Arrow 1931; Chandra 2009; Karimbumkara and Priyadarsanan 2013

Arrow 1931; Chandra 2009; Karimbumkara and Priyadarsanan 2013; Schoolmeesters 2019

Bezdĕk and Hájek 2013

Arrow 1931; Biswas and Chatterjee 1985; Sewak 2006

Karimbumkara and Priyadarsanan 2016

Frey 1962

Arrow 1931; Sewak 2006, 2009a, 2009b; Karimbumkara and Priyadarsanan 2013

Arrow 1931; Schoolmeesters 2019

Arrow 1931; Biswas and Chatterjee 1985; Sewak 2006; Karimbumkara and Priyadarsanan 2013

Arrow 1931; Chandra 2005; Sewak 2009a; Chandra and Gupta 2012a; Chandra et al. 2012c

Arrow 1931; Karimbumkara and Priyadarsanan 2013

Arrow 1931; Karimbumkara and Priyadarsanan 2013, 2016

Arrow 1931; Biswas and Chatterjee 1986a, 1991; Chandra

2000, 2005; Chandra and Ahirwar 2005a, 2007; Chandra and Gupta 2011a, 2012c, 2012d, 2012e, 2013; Chandra et al. 2012b 2012c; Karimbumkara and Priyadarsanan 2013; Gupta et al. 2014; Siddiqui et al. 2014; Gajendra and Prasad 2016; Anto and Vinod 2017

Arrow 1931; Biswas and Chatterjee 1985, 1986a; Chandra 2000, 2005; Chatterjee and Biswas 2000; Chandra and Singh 2004; Sewak 2006; Chandra and Ahirwar 2007; Jadhav and Sharma 2012; Chandra and Gupta 2012a, 2012c, 2012d; Chandra et al. 2012a, 2012c; Karimbumkara and Priyadarsanan 2013; Gupta et al. 2014; Gajendra and Prasad 2016; Singh et al. 2017

Arrow 1931; Biswas and Chatterjee 1986a, 1986b; Biswas and Chatterjee 1991; Chandra 2000, 2005; Chandra and Ahirwar 2005a, 2005b, 2007; Sewak 2009a, 2009b; Chandra and Gupta 2011a, 2012c, 2012d, 2013; Chandra et al. 2012a, 2012b, 2012c; Karimbumkara and Priyadarsanan 2013; Gupta et al. 2014; Gajendra and Prasad 2016;

Arrow 1931; Chandra 2005; Sewak 2009a; Karimbumkara and Priyadarsanan 2013

Arrow 1931; Biswas and Chatterjee 1985, 1986a; Chatterjee and Biswas 2000; Sewak 2006; AnithaRani and Sanjayan 2013; Karimbumkara and Priyadarsanan 2013; Muhaimin et al. 2015; Sathiandran et al. 2015; Schoolmeesters 2019

Arrow 1931; Sathiandran et al. 2015

Biswas and Chatterjee 1985; Sewak 2006

Biswas and Chatterjee 1985; Sewak 2006

Arrow 1931; Biswas and Chatterjee 1985; Chandra 2005; Sewak 2005, 2006; Schoolmeesters 2019

Arrow 1931; Biswas and Chatterjee 1985

Arrow 1931; Biswas and Chatterjee 1985; Sewak 2006

Arrow 1931; Biswas and Chatterjee 1986a, 1986b, 1991; Chatterjee and Biswas 2000; Chandra 2000; Chandra and Ahirwar 2005a, 2005b, 2007; Sewak 2006, 2009b; Chandra and Gupta 2012c, 2012d, 2013; Gajendra and Prasad 2016 


\begin{tabular}{ll}
\hline No. & Species \\
\hline 153 & Onthophagus sahai Biswas, 1986 \\
154 & $\begin{array}{l}\text { Onthophagus (Eremonthophagus) } \\
\text { semicinctus D'orbigny, } 1897\end{array}$ \\
155 & $\begin{array}{l}\text { Onthophagus (Serrophorus) seniculus } \\
\text { (Fabricius, } 1781\end{array}$ \\
156 & $\begin{array}{l}\text { Onthophagus (Colobonthophagus) } \\
\text { shillongensis Scheuern, 1995 }\end{array}$ \\
157 & Onthophagus sikkimensis Gillet, 1925 \\
158 & Onthophagus (Onthophagus) socialis \\
& Arrow, 1931 \\
159 & $\begin{array}{l}\text { Onthophagus songsokensis Biswas \& } \\
\text { Chatterjee, 1985 }\end{array}$ \\
160 & Onthophagus spinifex (Fabricius, 1781)
\end{tabular}

161 Onthophagus sternalis Arrow, 1931

162 Onthophagus (Strandius) subansiriensis Biswas, 1979

163 Onthophagus suillus Arrow, 1931

164 Onthophogus (Palaeonthophagus) sutleinensis Splichal, 1910

165 Onthophagus (Trichonthophagus) tarandus (Fabricius, 1792)

166 Onthophagus (Gibbonthophagus) taurinus White, 1844

167 Onthophagus tharalithae Karimbumkara Assam, Kerala \& Priyadarsanan, 2016

168 Onthophagus (Altonthophagus) tibetanus Arrow, 1907

169 Onthophagus tirapensis Biswas \& Chatterjee, 1985

170 Onthophagus tnai Nithya \& Sabu, 2012

171 Onthophagus (Colobonthophagus) tragus Madhya Pradesh, Maharasthra, Gujarat, Himachal (Fabricius, 1792)

172 Onthophagus (Eremonthophagus) Karnataka transcaspicus Koenig, 1889

173 Onthophagus (Colobonthophagus)

4 Onthophagus (Colobonthophagus) triceratops Arrow, 1913

175 Onthophagus tritinctus Boucomont, 1914 Karnataka, Kerala, Maharashtra, Nagpur, Odisha,

176 Onthophagus troglodyta (Wiedemann, Haryana, Punjab, Rajasthan, Uttarakhand, Uttar 1823)

177 Onthophagus (Matashia) troniceki Balthasar, 1933

178 Onthophagus truncaticornis (Schaller, 1783)

179 Onthophagus (Indonthophagus) turbatus Karnataka, Kerala, Maharashtra, Odisha, Walker, 1858

180 Onthophagus unifasciatus (Schaller, 1783)
Tamil Nadu

Arunachal Pradesh, Assam, Gujarat, Karnataka, Rajasthan, Tripura, West Bengal Tamil Nadu

Puducherry, Tamil Nadu

\section{Els
No
Pa
Mys
Nond
No
No
Ba
sta

Ba
No
Af
Pa}

No record found
Pakistan

Myanmar, China, Thai-

land, Vietnam

No record found

Bangladesh

No record found

No record found

Bangladesh, Nepal, Pakistan, Sri Lanka

No record found

Bangladesh, China, Myanmar, Thailand,

Vietnam

No record found

China

No record found

No record found

Bangladesh, China,

Indonesia, Korea, Laos,

Malaysia, Myanmar,

Thailand, Vietnam

Algeria, Arabia, Ethiopia, Iraq, Israel, Morocco, Pakistan, Somalia,

Sudan, Tajikistan, Turkey, Turkmenistan, Uzbekistan

No record found

No record found

China, Sri Lanka

Afghanistan, Pakistan Pradesh

Odisha

No record found

No record found

China, Myanmar, Sri Lanka, Thailand, Vietnam

Bangladesh, Sri Lanka harkhand, Karnataka, Kerala, Madhya Pradesh, Maharashtra, Punjab, Tamil Nadu, Uttarakhand, Uttar Pradesh, West Bengal

\section{References}

Biswas and Chatterjee 1986b

Arrow 1931; Sewak 2009a, 2009b, 2010; Karimbumkara and Priyadarsanan 2013

Arrow 1931; Sewak 1986, 1991, 2006, 2009a, 2009b, 2010

Schoolmeesters 2019

Scheuern 1995

Arrow 1931; Schoolmeesters 2019

Arrow 1931; Chandra 2005; Karimbumkara and Priyadarsanan 2013;

Biswas and Chatterjee 1985; Sewak 2006

Arrow 1931; Biswas and Chatterjee 1986a, 1986b; Chatterjee and Biswas 2000; Chandra 2005; Chandra and Gupta 2011b; Jadhav and Sharma 2012; Chandra and Gupta 2012b, 2012d, 2013; Chandra et al. 2012c; Karimbumkara and Priyadarsanan 2013; Gupta et al. 2014; Gajendra and Prasad 2016

Arrow 1931; Chandra et al. 2012c; Chandra and Gupta 2012e; Schoolmeesters 2019

Biswas 1979

Arrow 1931; Karimbumkara and Priyadarsanan 2013

Arrow 1931; Chandra 2009; Sewak 2005

Arrow 1931; Chandra 2000, 2009; Chandra and Ahirwar 2005a, 2005b; Chandra and Ahirwar 2007; Sewak 2009b; Jadhav and Sharma 2012; Chandra et al. 2012c; Chandra and Gupta 2012c, 2012d; Karimbumkara and Priyadarsanan 2013

Biswas and Chatterjee 1986b; Chatterjee and Biswas 2000; Schoolmeesters 2019

Karimbumkara and Priyadarsanan 2016

Arrow 1931; Sewak 2006; Chandra et al. 2012a, $2012 c$

Biswas and Chatterjee 1985; Sewak 2006

Nithya and Thomas 2012

Arrow 1931; Sewak 1986, 2009b, 2010; Chandra 2005, 2009; Chandra and Ahirwar 2005b; Huijbregts and Krikken 2009; Chandra et al. 2012c; Chandra and Gupta 2012c; Karimbumkara and Priyadarsanan 2013; Sarkar et al. 2015; Schoolmeesters 2019

Arrow 1931; Karimbumkara and Priyadarsanan 2013; Schoolmeesters 2019

Scheuern 1995; Chandra 2009

Arrow 1931; Biswas and Chatterjee 1985, 1986a; Chatterjee and Biswas 2000; Sewak 2006, 2009a; Karimbumkara and Priyadarsanan 2013; Sarkar et al. 2015

Arrow 1931; Biswas and Chatterjee 1991; Karimbumkara and Priyadarsanan 2013, 2016; Sathiandran et al. 2015

Arrow 1931; Sewak 2009b, 2010; Chandra et al. 2012c; AnithaRani and Sanjayan 2013

Bezděk and Hájek 2013

Arrow 1931; Chandra2009; Chandra and Gupta 2012c, 2012d; Karimbumkara and Priyadarsanan 2013

Arrow 1931; AnithaRani and Sanjayan 2013; Karimbumkara and Priyadarsanan 2013; Sathiandran et al. 2015; Schoolmeesters 2019

Arrow 1931; Oppenheimer 1977; Biswas and Chatterjee 1986b; Chandra 2009; Jadhav and Sharma 2012; Chandra et al. 2012b, 2012c; Chandra and Gupta 2012c, 2012d, 2013; Karimbumkara and Priyadarsanan 2013; Gajendra and Prasad 2016; Kalawate 2018 


\begin{tabular}{|c|c|c|c|c|}
\hline \multirow{2}{*}{ No. } & \multirow{2}{*}{ Species } & \multicolumn{2}{|l|}{ Distribution } & \multirow{2}{*}{ References } \\
\hline & & India & Elsewhere & \\
\hline 181 & $\begin{array}{l}\text { Onthophagus (Colobonthophagus) } \\
\text { urellus Boucomont, } 1919\end{array}$ & Tamil Nadu, Kerala & Myanmar & Arrow 1931; Chandra 2009 \\
\hline 182 & $\begin{array}{l}\text { Onthophagus (Colobonthophagus) } \\
\text { usurpator Balthasar, } 1959\end{array}$ & Karnataka, Kerala & No record found & Karimbumkara and Priyadarsanan 2013 \\
\hline 183 & $\begin{array}{l}\text { Onthophagus variegatus (Fabricius, } \\
\text { 1798) }\end{array}$ & $\begin{array}{l}\text { Arunachal Pradesh, Gujarat, Haryana, Punjab, } \\
\text { Rajasthan }\end{array}$ & $\begin{array}{l}\text { Afghanistan, Iran, } \\
\text { Iraq, Kenya, Namibia, } \\
\text { Pakistan, Soudi Arabia, } \\
\text { Tanzania, Zimbabwe }\end{array}$ & $\begin{array}{l}\text { Arrow 1931; Sewak 2006, 2009a, 2009b; Ali et al. 2015; School- } \\
\text { meesters } 2019\end{array}$ \\
\hline 184 & $\begin{array}{l}\text { Onthophagus (Paraphanaeomorphus) } \\
\text { vaulogeri Boucomont, } 1923\end{array}$ & $\begin{array}{l}\text { Arunachal Pradesh, Assam, Uttarakhand, } \\
\text { Meghalaya }\end{array}$ & $\begin{array}{l}\text { China, Laos, Myanmar; } \\
\text { Thailand; Vietnam }\end{array}$ & Biswas and Chatterjee 1985; Sewak 2006 \\
\hline 185 & $\begin{array}{l}\text { Onthophagus (Micronthophagus) } \\
\text { vigilans Boucomont, } 1921\end{array}$ & Bihar, Odisha, Rajasthan, & China, Laos, Vietnam, & Arrow 1931; Sewak 2009a, 2009b; Schoolmeesters 2019 \\
\hline 186 & Onthophagus violaceotinctus Gillet, 1925 & Andhra Pradesh, Gujarat, Tamil Nadu & No record found & Arrow 1931; Sewak 2009a \\
\hline 187 & Onthophagus vladimiri Frey, 1957 & Kerala, Tamil Nadu & No record found & $\begin{array}{l}\text { Biswas and Chatterjee 1986b; Chandra and Gupta 2012a; Sathi- } \\
\text { andran et al. 2015; Schoolmeesters } 2019\end{array}$ \\
\hline 188 & Onthophagus vulpinus Arrow, 1931 & Assam & Myanmar, Thailand & Arrow 1931; Schoolmeesters 2019 \\
\hline 189 & Onthophagus vultur Arrow, 1931 & Andhra Pradesh, Maharashtra, Karnataka & No record found & Arrow 1931; Karimbumkara and Priyadarsanan 2013, 2016 \\
\hline 190 & $\begin{array}{l}\text { Onthophagus (Onthophagus) zebra } \\
\text { Arrow, } 1931\end{array}$ & Madhya Pradesh, Maharashtra, Karnataka & No record found & $\begin{array}{l}\text { Arrow 1931; Chandra 2000; Chandra and Ahirwar 2007; Jadhav } \\
\text { and Sharma 2012; Chandra and Gupta 2012c, 2012d; Karim- } \\
\text { bumkara and Priyadarsanan } 2013\end{array}$ \\
\hline
\end{tabular}

